Supporting Information (SI) for

\title{
Sustainable Production of Acrylic Acid via 3-Hydroxypropionic Acid from Lignocellulosic Biomass
}

\author{
Sarang S. Bhagwat ${ }^{1,2}$, Yalin $L^{1,3}$, Yoel R. Cortés-Peña ${ }^{1,2}$,Emma C. Brace ${ }^{1,3}$, \\ Teresa A. Martin ${ }^{1,4}$, Huimin Zhao ${ }^{1,4}$, Jeremy S. Guest ${ }^{1,2,3, *}$ \\ ${ }^{1}$ DOE Center for Advanced Bioenergy and Bioproducts Innovation (CABBI), University of Illinois \\ at Urbana-Champaign, 1206 W. Gregory Drive, Urbana, IL 61801, USA \\ 2 Department of Civil and Environmental Engineering, University of Illinois at Urbana-Champaign, \\ 3221 Newmark Civil Engineering Laboratory, 205 N. Mathews Avenue, Urbana, IL 61801, USA \\ 3 Institute for Sustainability, Energy, and Environment (iSEE), University of Illinois at Urbana- \\ Champaign, 1101 W. Peabody Drive, Urbana, IL 61801, USA \\ 4 Department of Chemical and Biomolecular Engineering, University of Illinois at Urbana- \\ Champaign, 215 Roger Adams Laboratory, 600 S. Mathews Avenue, Urbana, IL 61801, USA \\ * Corresponding author; email: jsguest@illinois.edu
}

Number of pages: 30

Number of figures: 8

Number of tables: 4

\section{Table of Contents}

Section S1. Supplementary Process Description, Analysis Methods, and Results ................. S3

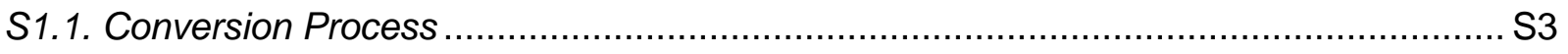

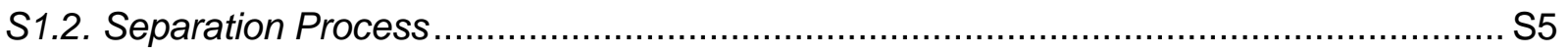

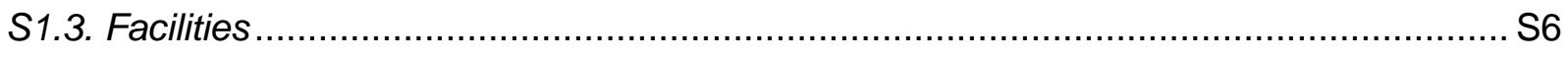

S1.4. Satisfying the Biorefinery's Heating, Cooling, and Electricity Demands and Method of Attributing Costs and Environmental Impacts ........................................................... S7

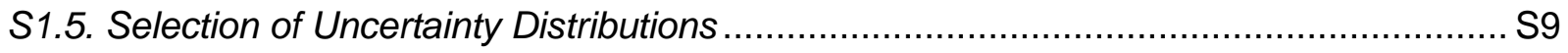

S1.6. Estimating Probability of Market-Competitiveness ............................................... S9

S1.7. Linking Feedstocks to the Biorefinery ............................................................. 110

S1.8. Quantifying the Benefits from the Heat Exchanger Network, Boiler, and Turbogenerator Facilities.....

S1.9. Comparing the Environmental Impacts of Sugar-Based Acrylic Acid Production with

Reported Data on Alternative Production Routes ....................................................... S11

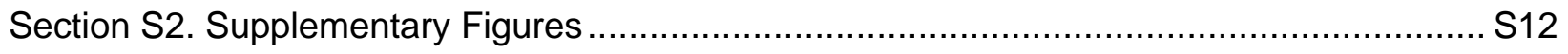

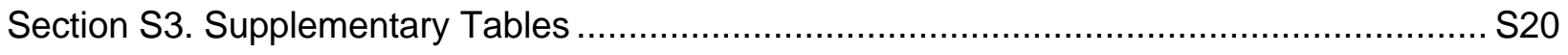

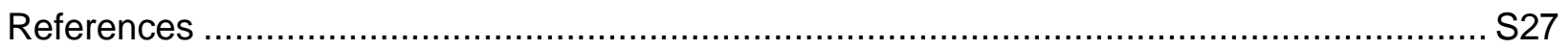




\section{List of Figures}

Figure S1. Biorefinery overview S12

Figure S2. Spearman's rho for all parameters included in the uncertainty analysis with respect to MPSP, GWP ${ }_{100}$, and FEC S13

Figure S3. MPSP, GWP ${ }_{100}$, and FEC across productivity $\mathrm{S} 14$

Figure S4. MPSP, GWP ${ }_{100}$, and FEC across the titer-yield performance space at lower-than-baseline productivity

Figure S5. MPSP, GWP ${ }_{100}$, and FEC across the titer-yield performance space at the higher-than-baseline productivity

Figure S6. Case-by-case method of satisfying system heating, cooling, and non-cooling electricity demands

Figure S7. MPSP, GWP ${ }_{100}$, and FEC across $1^{\text {st }}$ and $2^{\text {nd }}$ generation feedstock composition and price S18

Figure S8. Changes in MPSP, GWP 100 , and FEC with technological improvements S19

\section{List of Tables}

Table S1. List of major units and equipment included in the biorefinery S20

Table S2. Reference literature for design of co-fermentation units S23

Table S3. Considerations for the choice of solvent for 3-HP extraction $\mathrm{S} 24$

Table S4. List of parameters included in the uncertainty analysis S25 


\section{Section S1. Supplementary Process Description, Analysis Methods, and Results}

\section{S1.1. Conversion Process}

The biorefinery's capacity for incoming lignocellulosic feedstock is 2,000 dry metric tonnes per day (consistent with Humbird et al. ${ }^{1}$ ). For the baseline biorefinery, feedstock price and composition similar to those of corn stover were assumed. These feedstocks, which are assumed to have been pre-processed to meet certain quality specifications (e.g., size, ash, moisture ${ }^{2}$ ), are pretreated by dilute sulfuric acid to depolymerize the majority of the hemicellulose and a minor fraction of cellulose (i.e., glucan) into their respective sugar oligomers and monomers. The pretreated slurry is then conditioned and pumped to the conversion process (Figure 1A) for saccharification (enzymatic hydrolysis) of cellulose.

The conversion process includes a saccharification unit, a fermentation unit, a seed preparation unit, and auxiliary units for mixing, concentration, inhibitor removal, heat exchange, and seed holding. For the baseline design, in the saccharification unit, enzyme (purchased from external sources at $\$ 6.16 \cdot \mathrm{kg}^{-1}$ protein ${ }^{3}$ ) is added at a loading of $10 \mathrm{mg}$ protein per $\mathrm{g}$ cellulose to hydrolyze cellulose in the pretreated feedstock slurry into glucose, after which the saccharified stream is filtered to remove insoluble solids, treated for inhibitory compounds, and then transferred to the fermentation unit with addition of the seed culture and corn steep liquor (CSL, to provide nutrients). In the neutral fermentation scenario, quicklime is added during fermentation to neutralize the produced acids (3-HP and by-product acetic acid), and the amount of quicklime is set to $110 \%$ of the theoretical 1:2 quicklime-to-monobasic acid molar ratio (e.g., 0.55 mole of quicklime for 1 mole of 3-HP or acetic acid). In the low-pH fermentation scenario, it is assumed that acid-tolerant strains are used for fermentation, therefore quicklime addition is not needed.

For consistency with the " $\mathrm{n}^{\text {th }}$ plant" assumptions made in the rest of this study, the choice of fermentation configuration across all designs was based on operating ease at the industrial scale. A continuous co-fermentation reactor configuration was chosen for the afforded ease of controlling the microbial growth rate using only the feed rate. ${ }^{4}$ Additionally, the constraints associated with batch and fed-batch configurations - specifically, limited substrate addition per unit volume of the reactor and high turnover time - are relaxed for the continuous configuration. ${ }^{4}$

For the baseline design, an 84-h retention time was used for the saccharification tank (based on Humbird et al. ${ }^{1}$ ), and the retention time for the co-fermentation reactor was determined through the designated titer and productivity.

The saccharified stream needs further processing so that (i) the glucose and xylose are present at the concentrations required to achieve the targeted 3-HP concentration, and (ii) potentially inhibitory compounds (acetic acid, furfural, and hydroxymethyl furfural, which are introduced by the use of lignocellulose hydrolysate as opposed to pure sugars in the substrate medium $^{5}$ ) in the continuous co-fermentation tank remain at or below a total concentration of 1.0 $\mathrm{g} \cdot \mathrm{L}^{-1}$ (this limit is discussed below). To facilitate this, the saccharified stream is passed through a multiple-effect evaporator which initially concentrates the stream (to no more than $600 \mathrm{~g} \cdot \mathrm{L}^{-1}$ of total sugars to avoid deposition of solids) and evaporates a significant amount of the fermentation inhibitors. The stream is then diluted such that the steady-state concentration of 3-HP in the continuous co-fermentation tank is the target concentration (hereafter referred to as the titer), and such that the total concentration of fermentation inhibitors does not exceed $1.0 \mathrm{~g} \cdot \mathrm{L}^{-1}$. For the baseline design, a vapor fraction of 0.041 for the evaporator paired with a dilution increase of $4.5 \% \mathrm{~kg}$ water per $\mathrm{kg}$ original saccharified slurry (i.e., increasing the water content of the concentrated slurry from $82.87 \mathrm{wt} \%$ to $83.61 \mathrm{wt} \%$ ) was utilized to achieve the baseline 3-HP titer of $54.8 \mathrm{~g} \cdot \mathrm{L}^{-1}$ and a total inhibitor concentration of $0.96 \mathrm{~g} \cdot \mathrm{L}^{-1}$ at steady state in the co-fermentation reactor. It has been reported that Corynebacterium glutamicum (which, as discussed below, is the baseline fermentation microbe) can tolerate up to $6.0,2.5$, and $2.0 \mathrm{~g} \cdot \mathrm{L}^{-1}$ of acetic acid, furfural, 
and hydroxymethyl furfural (respectively) in isolation before severe inhibitory effects on growth are observed. ${ }^{5-7}$ Acetic acid is neutralized in the neutral fermentation scenario, and is assumed to have a negligible inhibitory effect in the low-pH fermentation scenario (as acid-tolerant microbes such as Saccharomyces cerevisiae have been shown to grow without severe inhibition by acetic acid at concentrations as high as 10 mol\% with overexpression of certain genes ${ }^{8}$ ). In combination, the inhibitory effects of furfural and hydroxymethyl furfural on fermentation strains can increase due to a synergistic effect. ${ }^{9}$ Although some C. glutamicum strains have been reported to withstand these inhibitors well even in combination, ${ }^{7}$ the inhibitory effects of these compounds (in isolation as well as in combination) can differ among strains, and therefore the fermentation feed is processed to have no more than $1.0 \mathrm{~g} \cdot \mathrm{L}^{-1}$ of furfural and hydroxymethyl furfural in total. This assumed maximum inhibitors concentration of $1.0 \mathrm{~g} \cdot \mathrm{L}^{-1}$ is justified by the relative insensitivity of results to changes in this assumption: at the baseline assumption of $1.00 \mathrm{~g} \cdot \mathrm{L}^{-1}$, MPSP was $\$ 1.831$ $\mathrm{kg}^{-1}$, GWP was $3.898 \mathrm{~kg} \mathrm{CO}$-eq $\cdot \mathrm{kg}^{-1}$, and FEC was $51.42 \mathrm{MJ} \cdot \mathrm{kg}^{-1}$; at $4.00 \mathrm{~g} \cdot \mathrm{L}^{-1}(300 \%$ higher than the baseline assumption), MPSP was $\$ 1.808 \mathrm{~kg}^{-1}$ (1\% lower than the baseline), GWP was

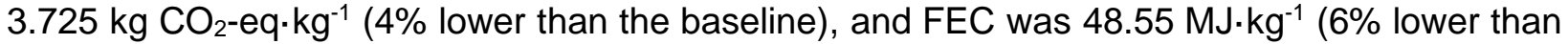
the baseline); at $0.25 \mathrm{~g} \cdot \mathrm{L}^{-1}$ (75\% lower than the baseline assumption), MPSP was $\$ 1.876 \mathrm{~kg}^{-1}$ ( $2 \%$ higher than the baseline), GWP was $4.362 \mathrm{~kg} \mathrm{CO}-\mathrm{eq} \cdot \mathrm{kg}^{-1}(12 \%$ higher than the baseline), and FEC was $59.30 \mathrm{MJ} \cdot \mathrm{kg}^{-1}$ (15\% higher than the baseline).

After evaporation, the concentrated stream is sent to the continuous co-fermentation tank. Co-fermentation operates under one of two scenarios: (i) neutral fermentation, in which neutrophilic strains are used and quicklime is used to continuously neutralize the generated 3$\mathrm{HP}$; and (ii) low-pH fermentation, in which acid-tolerant strains are used, eliminating the need for quicklime addition. Regardless of whether diauxic utilization - where glucose and xylose are used sequentially (as opposed to simultaneously) - occurs, its effect would already be reflected in the data given that overall co-fermentation parameters were used (e.g., yield calculated as overall yield of 3-HP on glucose and xylose rather than individual yield from glucose or xylose). As the multiple effect evaporator is set to concentrate the saccharified stream to no more than $600 \mathrm{~g} \cdot \mathrm{L}^{-1}$ of total sugars, there is an implicit maximum 3-HP titer that can be achieved at any given yield on sugars during co-fermentation. This manifests as an infeasible region in the upper-left portion of the fermentation titer-yield space (represented by white regions in Figures 3, 4, S4, and S5). Experimental fermentation metrics (e.g., titer, yield, productivity) were used to guide the design of the conversion process (Table S2), which were collected from literature that (i) converted only glucose or (ii) converted only xylose or (iii) converted both glucose and xylose (i.e., realized cofermentation) into 3-HP. The collected literature showed us that Corynebacterium is currently the most promising co-utilizing microbial candidate with the highest 3-HP titer and yield. To the best of our knowledge, only two existing papers have analyzed the fermentation performance of any species of Corynebacterium on sugars to produce 3-HP. ${ }^{10,11}$ Of those two papers, Chang et al. explored a novel route to produce 3-HP from glucose and acetate (rather than xylose) via the malonyl-CoA pathway, resulting in a 3-HP titer of $3.77 \mathrm{~g} \cdot \mathrm{L}^{-1}$ via batch fermentation. ${ }^{11}$ On the other hand, Chen et al. developed a strain capable of co-utilizing glucose and xylose (which is more closely aligned with our study's analyses), resulting in a titer of $54.8 \mathrm{~g} \cdot \mathrm{L}^{-1}$ via fed-batch fermentation. ${ }^{10}$ Thus, the Corynebacterium glutamicum strain developed by Chen et al. was selected as the current representative of baseline performance for co-fermentation of glucose and xylose to produce 3-HP.

A list of all units comprising the biorefinery, including conversion process units, is included in Table S1. A comprehensive analysis on the fermentation unit across the titer-yield performance space at varying productivities was also conducted (Figures 3, 4, S3, S4, and S5). 


\section{S1.2. Separation Process}

In the separation process (Figure 1B), solids (insoluble lignin, unutilized insoluble carbohydrates, etc.) in the fermentation broth are removed using a pressure filter modeled similarly to that described in Humbird et al. ${ }^{1}$ (step 1). Sulfuric acid is added to the filtrate in an acidulation tank to convert calcium 3-hydroxypropionate into 3-HP and gypsum $\left(\mathrm{CaSO}_{4}\right)$, the latter of which is filtered out in the subsequent gypsum filter (step 2). For the low-pH fermentation scenario, the acidulation reactor and gypsum filter are not included as the produced 3-HP is not converted to calcium 3hydroxypropionate in the fermenter.

Although there is ongoing development of industrial-scale systems for the production of acrylic acid from sugars via 3-HP, ${ }^{12}$ and several patents have been filed for the processes involved, ${ }^{13,14}$ there have been no successful (i.e., currently operational and with a net present value of at least 0 ) industrial implementations to date (to the best of our knowledge). Integrated routes for extractive bioconversion and reactive extraction have undergone promising development but are currently impeded by high solvent toxicity of and/or low acid tolerance by the fermentation microbes. ${ }^{15,16}$ The guiding criterion (other than minimizing costs and using wellestablished unit operations) during the synthesis of our separation process was to avoid recovery of 3-HP as the top-product of any evaporation or distillation unit operation so as to limit the likelihood of thermal degradation of 3-HP. This excluded the sole use of vacuum distillation to separate 3-HP from lower- and higher-boiling impurities. Instead, we designed a solvent extraction process to separate 3-HP from higher-boiling impurities (such as dissolved cellulosic components and saccharification enzyme) and coupled this with evaporative separation methods (under reduced pressure) before as well as after solvent extraction to separate 3-HP from lowerboiling impurities (Figure 1A). Fifteen candidate solvents (Table S3) were considered for the extraction of 3-HP. For final selection of the solvent, the solute-into-extract partition coefficient $(K)$ was maximized with the following constraints: (i) boiling point of the solvent should be lower than 3-HP (to enable recovery of solvent as the top product of distillation, thus minimizing the risk of thermal decomposition of 3-HP); (ii) water-into-organic-phase $K<0.5$ (to limit dilution of the recovered solvent for recycle); (iii) solvent-into-aqueous-phase $K<0.05$ (to limit solvent loss); and (iv) acetic acid-into-organic-phase $K$ and glycerol-into-organic-phase $K$ should both be under 1.00 (to limit presence of impurities in the dehydration reactor). Of the fifteen candidate solvents for which liquid-liquid equilibrium was simulated, 1-hexanol was the only solvent that satisfied all constraints in addition to being the solvent with the second-highest solute-into-organic-phase $K$, and was thus selected for extraction of 3-HP.

After filtration of gypsum (or directly after filtration of cell mass in the low-pH fermentation scenario), water and a large portion of volatile organics (acetic acid, furfural, and hydroxymethyl furfural) are evaporated out of the solution (step 3), and the crude concentrated 3-HP stream (roughly $26 \mathrm{wt} \% 3-\mathrm{HP}$ in water along with dissolved post-fermentation impurities) is directed to a multi-stage mixer-settler configuration (15 stages in the baseline design) for solvent extraction wherein hexanol is used to extract 3-HP (step 4). The raffinate is sent to the boiler, while the extract (roughly $81.5 \mathrm{wt} \%$ hexanol, $12.7 \mathrm{wt} \% 3-\mathrm{HP}$, and $5.8 \mathrm{wt} \%$ water) is sent to a distillation column (step 5) wherein low pressure is maintained such that the temperature of neither the top nor bottom product exceeds $143^{\circ} \mathrm{C}$ in order to avoid thermal decomposition of 3-HP. While the exact temperature at which onset of 3-HP thermal decomposition occurs was not available in the literature, it has been reported (i) that 3-HP decomposes before it boils at standard pressure, ${ }^{17}$ that (ii) that the predicted boiling temperature disregarding decomposition is around $212-303^{\circ} \mathrm{C}$ at standard pressure, ${ }^{18-20}$ and (iii) that no thermal decomposition was observed to occur at as high as $143^{\circ} \mathrm{C}$ at standard pressure after temperature swing back-extraction from organic to aqueous phase..$^{21}$ Therefore, $143^{\circ} \mathrm{C}$ was chosen as the maximum allowable temperature in the distillation column. 
The top product $(93.4 \mathrm{wt} \%$ hexanol) is recycled to the solvent extraction unit. The bottom product (99.4 wt\% 3-HP) is diluted to 30 wt\% 3-HP (step 6) as required by the subsequent dehydration reactor to which it is directed (step 7). In the dehydration reactor, 3-HP is converted to acrylic acid at $80 \%$ conversion. The dilution requirement and conversion were chosen for consistency of assumptions with Dunn et al. ${ }^{22}$ and GREET $2020^{7}$. Based on experimental data from Dishisha et al., ${ }^{23}$ the following assumptions were made for the dehydration reactor design: stainless steel 316 as the material of construction; a residence time of $38.3 \mathrm{~h}$; an operating temperature of $230{ }^{\circ} \mathrm{C}$ and standard pressure $(1 \mathrm{~atm})$ for gas-phase dehydration; the catalyst (titanium dioxide; $\mathrm{TiO}_{2}$ ) loaded at a weight hourly space velocity of $0.125 \mathrm{~kg} 3-\mathrm{HP} \cdot \mathrm{kg}^{-1} \mathrm{TiO}_{2} \cdot \mathrm{h}^{-1}$. The costs and environmental impacts of catalyst deactivation, regeneration, and waste are assumed to be adequately characterized by the costs and environmental impacts associated with replenishing the catalyst at an annual rate of $100 \%$. The dilute acrylic acid produced from 3-HP dehydration is first condensed to a vapor fraction of zero and then sent to a distillation column (part of step 8) from which the top product (hot, 99.7\% water) is recycled to the dehydration reactor. The bottom product (roughly $76 \mathrm{wt} \%$ acrylic acid and $24 \mathrm{wt} \% 3-\mathrm{HP}$ ) is cooled to $89{ }^{\circ} \mathrm{C}$ and then pumped to another distillation column (part of step 8) where unreacted 3-HP (roughly $99.8 \mathrm{wt} \%$ ) is recovered as the bottom product and recycled to the dehydration reactor; the top product is glacial acrylic acid (at least $99.6 \mathrm{wt} \%$ purity across all analyses), which is cooled to 25 ${ }^{\circ} \mathrm{C}$ and sent to storage. The two distillation columns in step 8 have streams that are rich in either 3-HP or acrylic acid; vacuum is maintained in both columns such than no stream rich in 3-HP exceeds $143^{\circ} \mathrm{C}$ (to avoid thermal degradation) and no stream rich in acrylic acid exceeds $89{ }^{\circ} \mathrm{C}$ (to avoid polymerization of acrylic acid, which occurs above $90{ }^{\circ} \mathrm{C}^{24}$ ). In order to achieve glacial acrylic acid purity in step 8, breaking of the minimum-boiling water-acrylic acid azeotrope would be required. This has reportedly been achieved ${ }^{25}$ using two distillation columns of 17 and 34 theoretical stages (with the first column utilizing toluene to form an azeotrope with water and requiring no more than 0.016 moles of make-up toluene per mole of acrylic acid product, and with the second being a conventional distillation column). In this study, for the same purpose, two conventional distillation columns of 35 and 15 theoretical stages are designed (step 8; modeled using the Fenske-Underwood-Gilliland method $^{26}$ ) as limitations in BioSTEAM currently prevent modeling of the azeotrope column presented in ${ }^{25}$. As the two designed columns (step 8) accounted for approximately $5 \%$ of the total installed equipment cost and $2 \%$ of the annual variable operating cost, it is assumed that implementation of the azeotrope column reported in ${ }^{25}$ would not significantly alter the MPSP, GWP ${ }_{100}$, or FEC. Additionally, although the market for glacial acrylic acid often requires a purity of $98.0-99.5 \mathrm{wt} \%,{ }^{27}$ all biorefinery configurations in this work conservatively ensured a minimum purity of $99.6 \mathrm{wt} \%$. The distillation column designed for solvent recovery (step 5) is modeled using the McCabe-Thiele method. ${ }^{26}$ The use of more detailed distillation models (e.g., those utilizing rigorous distillation calculations ${ }^{28}$ ) could influence results, but investigating these effects was outside the scope of this work. The thermodynamic package utilized for all separation unit models was Thermosteam. ${ }^{29-31}$ Thermosteam's vapor-liquid equilibrium (VLE) algorithm solved the modified Raoult's law equation with activity coefficients estimated through UNIQUAC Functional-group Activity Coefficients (UNIFAC) interaction parameters. ${ }^{29,31} \mathrm{~A}$ list of all units comprising the biorefinery, including separation process units, is included in Table S1.

\section{S1.3. Facilities}

Wastewater streams are treated by anaerobic digestion (AD, producing biogas for on-site heat and electricity), an aerobic membrane bioreactor, reverse osmosis, and sludge dewatering units; the treated wastewater is reused in other processes. Wastewater sludge is dewatered by a centrifuge. Solid residuals from the conversion and separation processes (solid/liquid separation 
steps in Figure 1, containing lignin, unconverted cellulose and hemicellulose, and fermentation microbes), biogas from anaerobic digestion, and wastewater sludge are sent to the boiler and burned to reduce waste and recover energy. Given that energy recovered from the combustion cannot generate enough steam to meet the total heating demand of the biorefinery, natural gas is purchased as a supplementary fuel ${ }^{3,32}$ to satisfy the excess energy demand. Cooling demand is managed by the cooling tower and chilled water system facilities, which use electricity to regenerate cooling utilities (cooling water and chilled water, respectively). Water usage throughout the biorefinery is managed by the process water center unit, which supplements water needs (in addition to water recycled from the reverse osmosis unit) with fresh makeup water. The product (glacial acrylic acid, at least $99.6 \mathrm{wt} \%$ purity, $25^{\circ} \mathrm{C}$ ) is stored in a stainless steel 316 tank prior to sale.

To reduce total heating and cooling utility demands, a heat exchanger network (HXN) is implemented. The physical location of the HXN facility is distributed across the relevant units (rather than having a centralized configuration) to minimize heat lost during pumping. For each simulation, an initial pinch analysis is conducted to identify the pinch temperature and minimum energy targets, and viable pairs of hot and cold streams throughout the system are then matched on either side of the identified pinch. Subsequently, these matches are rigorously modeled using vapor-liquid equilibrium and simulated as process heat exchangers to calculate the offset to the utility demands of the original heat exchangers a process flowsheet of the entire HXN is available online. $\left.{ }^{33}\right)$. A list of all units comprising the biorefinery, including facilities, is included in Table S1.

\section{S1.4. Satisfying the Biorefinery's Heating, Cooling, and Electricity Demands and Method of Attributing Costs and Environmental Impacts}

Across the biorefinery, various unit operations exercise heating, cooling, and electricity utility demands, which are satisfied by direct use of steam, cooling/chilled water, and electricity, respectively (Figure S6). Steam is produced in the boiler by combustion of wastes and biogas (from AD). When the heat generated from wastes and AD biogas is inadequate, natural gas is purchased to satisfy the remainder of the system heating demand. Cooling and chilled water are produced in the cooling tower and chilled water package, respectively, which utilize electricity for this purpose. Electricity is produced by the turbogenerator using steam remaining after satisfying the system heating demand. When not enough steam remains to satisfy the system electricity demand, the biorefinery may either (i) purchase natural gas to produce additional steam in the boiler, or (ii) purchase electricity directly, depending on which of the two alternatives results in lower costs and environmental impacts. For the unit purchase prices and impact characterization factors utilized by this study, installation of a turbogenerator and purchase of natural gas resulted in lower MPSP ( $\$ 1.83 \mathrm{~kg}^{-1} \mathrm{vs}$. $\$ 1.86 \mathrm{~kg}^{-1}$ for the baseline) as well as lower impacts $\left(3.90 \mathrm{~kg} \mathrm{CO}_{2} \mathrm{CO}^{-}\right.$ eq $\cdot \mathrm{kg}^{-1}$ vs. $4.17 \mathrm{~kg} \mathrm{CO}{ }_{2}^{-} \mathrm{eq} \cdot \mathrm{kg}^{-1}$ and $51.4 \mathrm{MJ} \cdot \mathrm{kg}^{-1} \mathrm{vs} .51 .8 \mathrm{MJ} \cdot \mathrm{kg}^{-1}$ for the baseline) than purchase of electricity. Therefore, for biorefineries producing acrylic acid from $1^{\text {st }}$ as well as $2^{\text {nd }}$ generation feedstocks, natural gas was purchased to supplement steam production to satisfy the system heating and electricity demands (in addition to the steam that could be produced from combustion of wastes and AD biogas).

We may therefore consider a "pool" of steam produced by the boiler that is used to satisfy all of the system heating demand and can additionally be used to satisfy some portion of the system cooling and electricity demands. To determine the contributions of these demands toward the annual variable operating cost and environmental impacts of acrylic acid, the following set of equations were used:

$$
\begin{aligned}
& M_{S H D}=\text { steam }_{S H D} \times C_{\text {steam }} \\
& M_{S C D}=\text { steam }_{S C D} \times C_{\text {steam }}+\text { electricity }_{S C D} \times C_{\text {electricity }}
\end{aligned}
$$


$M_{S N C E D}=$ steam $_{S N C E D} \times C_{\text {steam }}+$ electricity $_{S N C E D} \times C_{\text {electricity }}$

where

$M$ is the contribution to the annual variable operating cost or total environmental impacts $\left(\mathrm{GWP}_{100}\right.$ or FEC) associated with any of the demands (SHD, system heating demand; $S C D$, system cooling demand; $S N C E D$, system electricity demand other than that used to produce cooling/chilled water),

steam $_{S H D}$ is the amount of produced steam (enthalpy flow units) that is used to satisfy the SHD,

steam $_{S C D}$ is the amount of produced steam that is used to generate electricity to satisfy the SCD,

steam $_{S N C E D}$ is the amount of produced steam that is used to generate electricity to satisfy the SNCED,

$C_{\text {steam }}$ is the variable operating cost or environmental impact associated with the production of a unit amount of steam,

electricity $_{S C D}$ is the amount of directly purchased electricity (power units) that is used to satisfy the SCD,

electricity $_{\text {SNCED }}$ is the amount of directly purchased electricity (power units) that is used to satisfy the SNCED, and

$C_{\text {electricity }}$ is the variable operating cost or environmental impact associated with the purchase of a unit amount of electricity.

Furthermore, the variable operating cost or environmental impacts associated with the production of a unit amount of steam can be determined using the following equation:

$C_{\text {steam }}=N G \times C_{N G}+B G E \times C_{B G E}$

where

$N G$ is the amount of natural gas purchased (mass units),

$C_{N G}$ is the variable operating cost or environmental impact associated with the acquisition of a unit amount of natural gas,

$B G E$ is the boiler gas-phase emissions stream, and

$C_{B G E}$ is the variable operating cost or environmental impact associated with the release of a unit amount of boiler gas-phase emissions (depends on the composition of the emissions stream).

Our goal behind quantifying the individual contributions of system heating, cooling, and non-cooling electrical demands was to enable a discussion of the relative benefits that could be achieved through improvements to different aspects of the biorefinery; e.g., looking at the relative contribution of the system heating demand to the variable operating cost, it may be suggested that the most beneficial improvement to the separation process would be one that minimizes the need for evaporation of water prior to solvent extraction. We believe that the framework described above is one that facilitates this discussion without increasing the overall costs and environmental impacts. 


\section{S1.5. Selection of Uncertainty Distributions}

In order to reflect the uncertainties in the parameters, a tiered system was used to determine the types and ranges of uncertainty distributions (specific distributions and references listed in Table S4):

1. For feedstock GWP 100 and FEC characterization factors, we applied uniform distributions due to limited data availability.

2. For parameters with more than 20 data points, we applied triangular distributions and used $5^{\text {th }}, 50^{\text {th }}$, and $95^{\text {th }}$ percentiles as the lower bound, most probable (also baseline), and upper bound.

3. For parameters with 5-20 data points (e.g., natural gas price), we applied triangular distributions and used the minimum, average, and maximum literature value as the lower bound, most probable (also baseline), and upper bound.

4. For parameters where the distributions themselves were from literature and the distributions were interpreted to be defined based on experimental data (e.g., pretreatment solids loading), we applied triangular distributions and used the minimum, baseline, and maximum values from the literature distribution (or $90 \%, 100 \%$, and $110 \%$ of the baseline if minimum and maximum values were lacking) as the lower bound, most probable (also baseline), and upper bound.

5. For parameters where the distributions were from literature, but the literature did not note the origin of the value (e.g., boiler efficiency), we used the same baseline value as the literature and chose uniform distribution with the minimum and maximum values from the literature distribution as the lower and upper bounds.

6. For fermentation yield and titer of 3-HP, as well as fermentation yield of acetic acid and glycerol, we applied a triangular distribution from $80 \%$ (minimum) to $120 \%$ (maximum) of the baseline (most probable) values to characterize the implications of uncertainty in the current fermentation performance of the microbial candidate C. glutamicum.

For all uncertainty analyses, samples were generated for each of the parameters listed in Table S4 using Latin hypercube sampling to reduce the number of simulations needed to yield reproducible results. This approach to defining probability density functions is consistent with that used in a prior work on lignocellulosic biorefineries. ${ }^{34}$

\section{S1.6. Estimating Probability of Market-Competitiveness (PMC)}

To characterize the probability of the produced acrylic acid being competitive with prevailing market prices - not only for the baseline design, but also over a breadth of improvements to fermentation performance - an uncertainty analysis (with 500 Monte Carlo simulations) was conducted at each of 225 distinct titer-yield combinations. The uncertainty distributions described (Section S1.5 and Table S4), other than for titer and yield, were utilized at every point in the analyzed titer-yield space at the baseline productivity $\left(0.76 \mathrm{~g} \cdot \mathrm{L}^{-1} \cdot \mathrm{h}^{-1}\right)$ for both neutral and low-pH fermentation scenarios. Thus, each point in the titer-yield space was associated with a distribution of possible MPSP values. This distribution was compared with the assumed market range (uniformly distributed between $\$ 1.40-1.65 \mathrm{~kg}^{-1}$ ) to obtain the probability of the MPSP being no more than the market price - which was defined as the probability of market-competitiveness and this was estimated at each point in the titer-yield space (Figure 3C,D). The steps to obtain the probability of market-competitiveness at a given point are: (i) conducting the described uncertainty analysis at the given point; (ii) obtaining a distribution of possible MPSP values; (iii) calculating the fraction of market price values (from the assumed market range) that are lower 
than or equal to each MPSP value; and (iv) calculating the average of all the obtained fractions, which is the probability of market-competitiveness at the given point.

Probability of market-competitiveness may be used as a comparative metric between alternative biorefinery designs. To some degree, it may also be used to make qualitative assertions: a probability of market-competitiveness $50 \%$, for instance, could signify the point beyond which a 3-HP biorefinery would be more likely to commercially succeed (net present value of at least zero) than fail, and $95 \%$ could signify a high likelihood of commercial success. Such qualitative assertions should be thoroughly qualified with market assumptions, however - such as the fact that temporal fluctuations in the market, including those induced by changes to product supply and demand, were not considered in this analysis. The main purpose of PMC in this study is to improve understanding of uncertainty in MPSP across co-fermentation titer and yield combinations.

\section{S1.7. Linking Feedstocks to the Biorefinery}

Lignocellulosic biomass can be obtained from diverse sources (e.g., bioenergy crops and agroindustrial wastes), and the compositions and prices of these feedstocks could vary significantly. ${ }^{35,36}$ Additionally, the supply chain of lignocellulosic feedstocks has not been established and no mature market exists for such feedstocks. ${ }^{35,37,38}$ Therefore, the effects of varying feedstock composition and prices on the MPSP were analyzed (Figure S7A). Under the same yield (49\% theoretical), titer $\left(54.8 \mathrm{~g} \cdot \mathrm{L}^{-1}\right)$, and productivity $\left(0.76 \mathrm{~g} \cdot \mathrm{L}^{-1} \cdot \mathrm{h}^{-1}\right)$ assumptions as the baseline, with neutral fermentation, the cost of low-carbohydrate feedstocks such as grass clippings (29 dw\% carbohydrates) needed to be lower than $\$ 4$ dry to ${ }^{-1}$ for the produced acrylic acid to be competitive with the upper market price range $\left(\$ 1.65 \mathrm{~kg}^{-1}\right)$. The MPSP was not competitive with the lower market price $\left(\$ 1.40 \mathrm{~kg}^{-1}\right)$ even if the grass clippings were acquired at no cost. For high-carbohydrate feedstocks such as switchgrass (67 dw\% carbohydrates), the biorefinery could afford a feedstock price of up to $\$ 64$ dry ton ${ }^{-1}$ with the resulting MPSP remaining within or under the market range. If, for example, only around $50 \%$ carbohydrate content could be realized at the baseline feedstock price $\left(\$ 71.3\right.$ dry ton $\left.{ }^{-1}\right)$ and the price would be doubled for feedstocks with the baseline carbohydrate content $\left(59 \%{ }^{37}\right)$, it would be more economical to set $50 \%$ rather than $59 \%$ as the target for feedstock carbohydrate content for lower MPSP.

For $1^{\text {st }}$ generation feedstocks (e.g., sugarcane and sweet sorghum), which contain sugars (e.g., glucose and sucrose), the biorefinery was assumed to operate for 200 days annually, and all assumptions (other than feedstock composition and price, which were varied; Figure S7B) were consistent with those made in BioSTEAM's sugarcane biorefinery. ${ }^{39}$ Under the same yield (49\% theoretical), titer $\left(54.8 \mathrm{~g} \cdot \mathrm{L}^{-1}\right)$, and productivity $\left(0.76 \mathrm{~g} \cdot \mathrm{L}^{-1} \cdot \mathrm{h}^{-1}\right)$ assumptions as the baseline, with neutral fermentation, the MPSP was $\$ 1.91 \mathrm{~kg}^{-1}$, which is modestly higher than for the baseline biorefinery (i.e., $\$ 1.83 \mathrm{~kg}^{-1}$, utilizing corn stover as the feedstock and operating for 328.5 days annually). Assuming that sweet sorghum has a dry weight total sugar content (reportedly 50.7 d.w.\% as glucose, sucrose, and fructose ${ }^{40}$ ) similar to that of sugarcane (reportedly 49.7 d.w. \% as glucose and sucrose ${ }^{39}$ ) as well as the same purchase price as sugarcane ( $\$ 104$ dry ton ${ }^{1}$ ), and if the sugarcane biorefinery were assumed to operate for 300 days annually (to simulate a supply of sugarcane for 200 days and a supply of sweet sorghum for 100 days annually), the MPSP of the produced acrylic acid would decrease to $\$ 1.68 \mathrm{~kg}^{-1}$, which is almost competitive with the upper market price $\left(\$ 1.65 \mathrm{~kg}^{-1}\right)$.

\section{S1.8. Quantifying the Benefits from the Heat Exchanger Network and Boiler Facilities}

By pairing available hot and cold streams, the HXN offset $29 \%$ [16 - 34\%] and 22\% [12 - 27\%] of the system heating and cooling demand, respectively, with a trivial $(\sim 1 \%)$ increase to total capital cost. A process flowsheet of the entire HXN is available online. ${ }^{33}$ Without implementing 
the $\mathrm{HXN}$, the system heating demand would account for $\sim 15 \%$ of the annual variable operating cost instead of the observed 9\% [7\% - 12\%]; additionally, the MPSP, GWP 100 , and FEC would increase to $\$ 1.95 \mathrm{~kg}^{-1}, 5.24 \mathrm{kgCO}$-eq $\cdot \mathrm{kg}^{-1}$, and $73.2 \mathrm{MJ} \cdot \mathrm{kg}^{-1}$, respectively $(6 \%, 34 \%$, and $42 \%$ higher than the baseline, respectively).

Without the combustion of biorefinery wastes (such as cellular debris and unconsumed sugars) and biogas (from anaerobic digestion) in the boiler along with supplementary natural gas, the variable operating cost associated with steam production (to satisfy the system heating, cooling, and non-cooling electricity demands) would have been around 4.5 times higher (due to the purchase of natural gas).

\section{S1.9. Comparing the Environmental Impacts of Sugar-Based Acrylic Acid Production with Reported Data on Alternative Production Routes}

Across Monte Carlo simulations, both GWP $_{100}$ and FEC were consistently (i.e., in every simulation) lower than those of fossil-based acrylic acid reported in GREET (2020) ${ }^{41}$ (by 33\% [20 $-41 \%$ ] for GWP $_{100}$, Figure 2B; by 55\% [45 - 62\%] for FEC, Figure 2C). A similar decrease in impacts by use of renewable feedstocks has been reported by Dunn et al. ${ }^{22}$ in whose study a decrease of $56 \%$ in GWP $_{100}$ and $62 \%$ in FEC was reported when switching from fossil-based to algal glycerol-based acrylic acid production. Our baseline biorefinery performed very similarly (approximately 4\% lower GWP 100 and 5\% higher FEC) when compared with fossil-based acrylic acid in ecoinvent 3.7.1, ${ }^{42,43}$ which assumes a requirement of natural gas for heating that is less than one-fourth that assumed by GREET (2020); results from 43\% (for GWP 100 ) and 66\% (for FEC) of simulations in our uncertainty analysis resulted in environmental impacts exceeding those reported for fossil-based acrylic acid in ecoinvent 3.7.1.

The baseline cradle-to-grave GWP 100 and FEC impacts for bio-based acrylic acid production estimated by our study are similar to those reported in Dunn et al. and moderately higher (by approximately $24 \%$ and $29 \%$, respectively) than those reported in GREET (2020). ${ }^{22,41}$ The Dunn study, which used algal glycerol as the feedstock in their simulation, assumed a fermentation 3HP titer of $27 \mathrm{wt} \%$ as opposed to our study's baseline titer of $\sim 5.2 \mathrm{wt} \%$ (i.e., $54.8 \mathrm{~g} \cdot \mathrm{L}^{-1}$, which represents the state of the art for sugar-based 3-HP production)..$^{22}$ If we made the assumption of increase in concentration of 3-HP in the fermentation broth from 5.2 wt\% to 27 wt\% without any additional cost (i.e., an evaporator without utilities and without equipment cost), we found that our biorefinery's baseline impacts would decrease to a GWP 100 of $2.92 \mathrm{~kg} \mathrm{CO}$-eq $\cdot \mathrm{kg}^{-1}$ and FEC of $35.3 \mathrm{MJ} \cdot \mathrm{kg}^{-1}$, which are moderately lower (by approximately $21 \%$ and $24 \%$, respectively) than the impacts reported in Dunn et al. and similar to those reported in GREET (2020) for algal glycerolderived acrylic acid. ${ }^{22,41}$ 
Section S2. Supplementary Figures

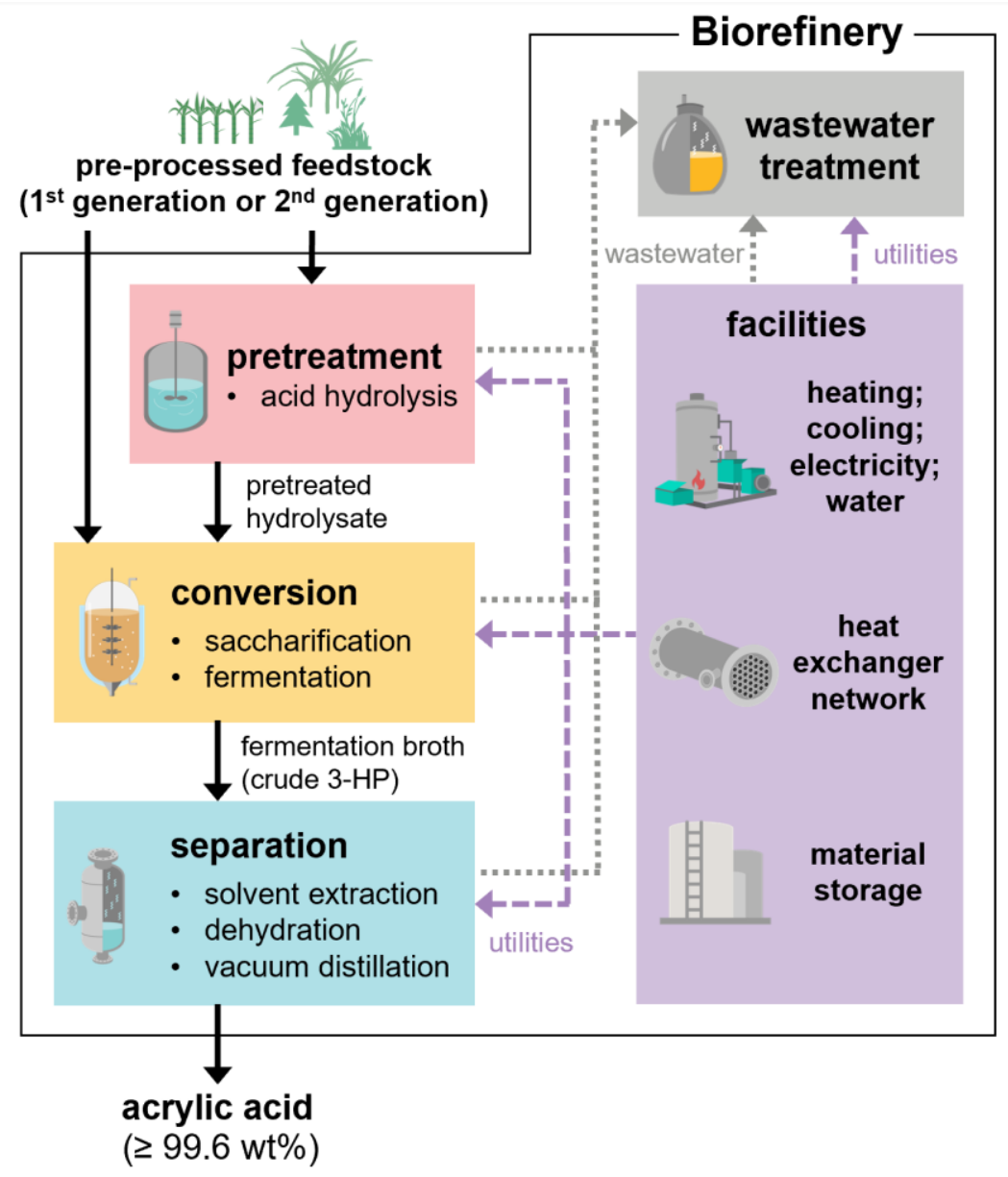

Figure S1. Overview of the biorefinery designed in this study. Pretreatment, conversion, and separation are inside-battery-limit processes; wastewater treatment and facilities are outside-battery-limit processes. 


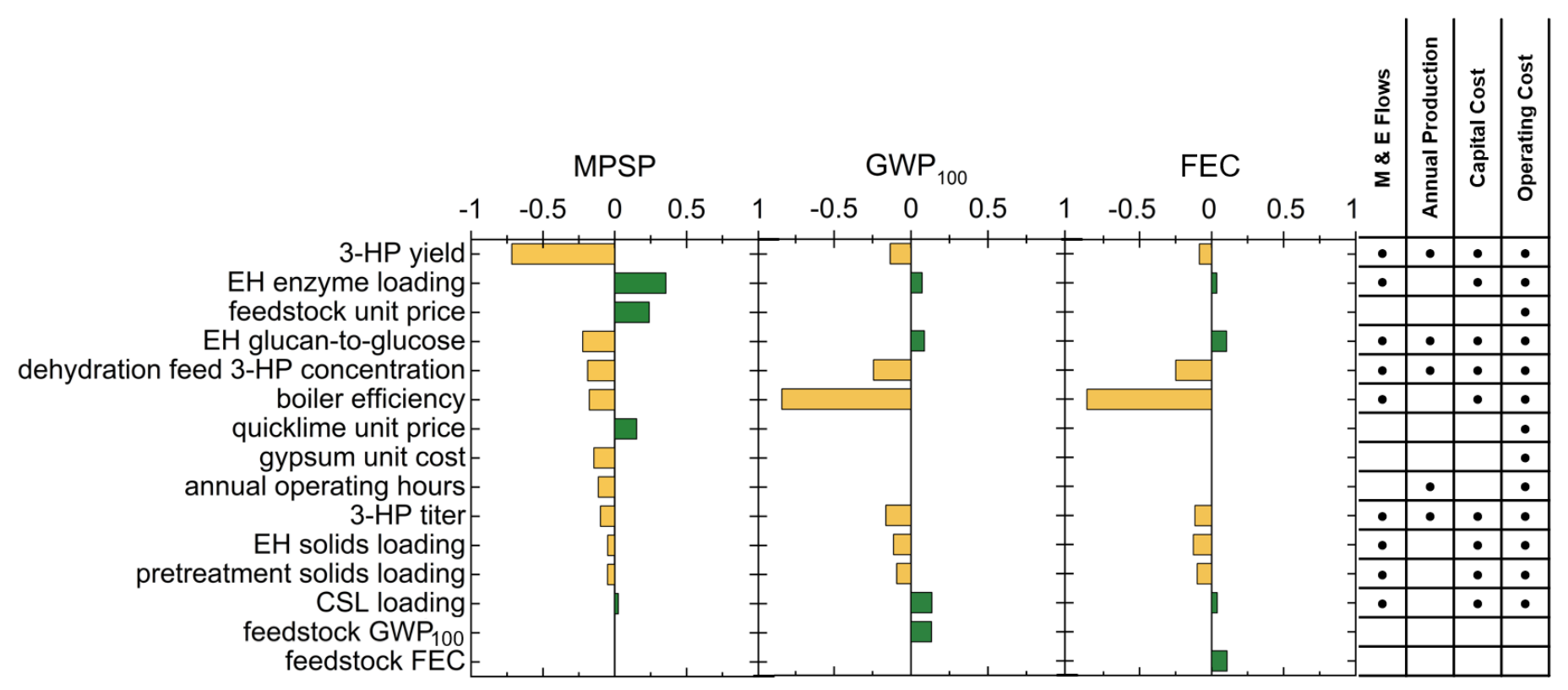

Figure S2. Spearman's rho $(\rho)$ values between input parameters and MPSP, GWP ${ }_{100}$, and FEC. EH represents enzymatic hydrolysis (i.e., saccharification) of feedstock. EH enzyme loading represents the amount of enzyme added per gram of cellulose during EH. Filled circles in the table on the right indicate the parameters that affect biorefinery mass and energy ( $\mathrm{M} \& \mathrm{E}$ ) flows, annual acrylic acid production, capital cost, and operating cost. A total of 37 parameters were selected for sensitivity analysis (full list, distributions, and $\rho$ values included in Table S4) and only parameters with absolute values of $\rho \geq 0.1$ for at least one of the three metrics - MPSP, GWP ${ }_{100}$, and FEC - are shown. 


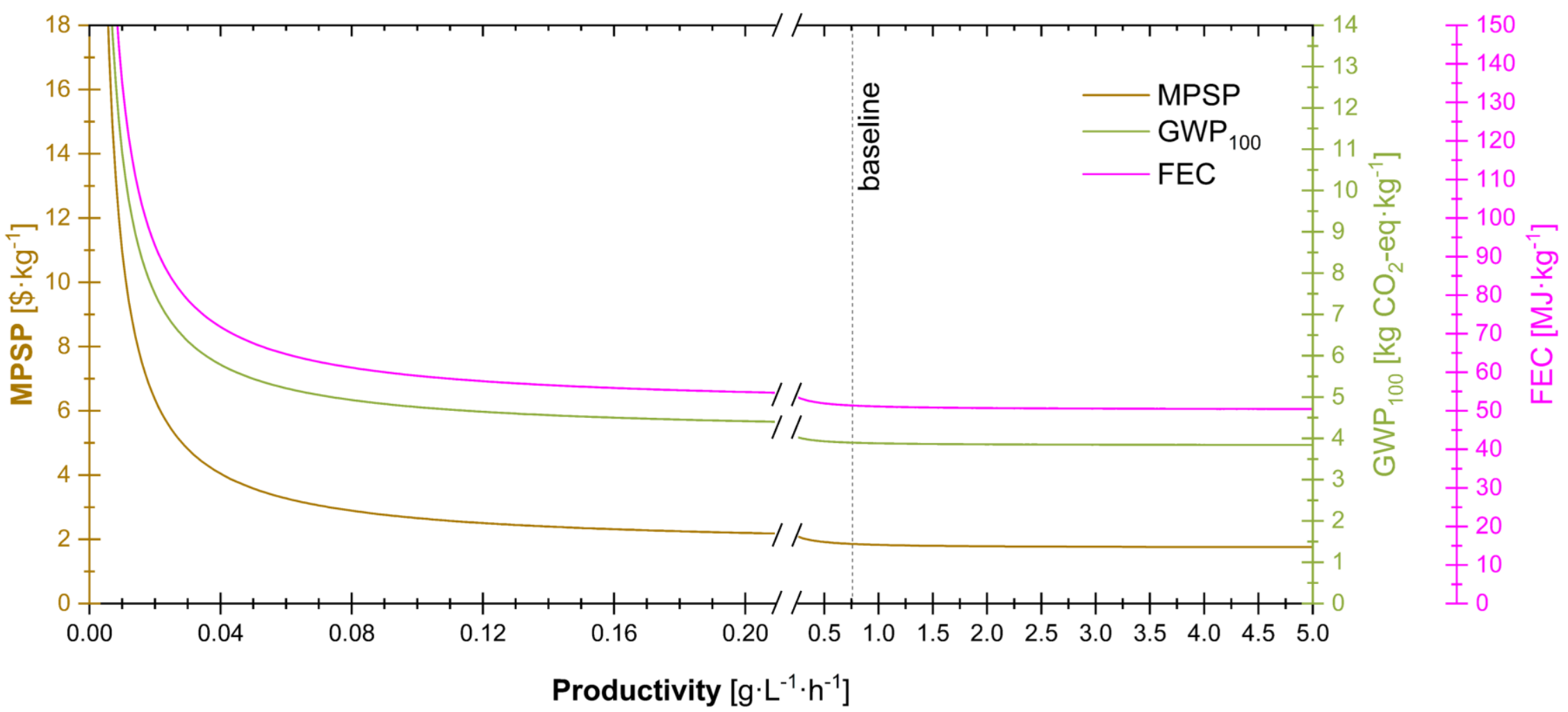

Figure S3. Minimum product selling price (MPSP), 100-year global warming potential (GWP 100 ), and fossil energy consumption (FEC) across fermentation 3-HP productivity. Simulations were conducted at the baseline yield (49\% of theoretical) and titer $\left(54.8 \mathrm{~g} \cdot \mathrm{L}^{-1}\right)$ with productivity values ranging from 0.001 to $5.0 \mathrm{~g} \cdot \mathrm{L}^{-1} \cdot \mathrm{h}^{-1}$ (before the $\mathrm{x}$-axis break, the step size is $0.001 \mathrm{~g} \cdot \mathrm{L}^{-1} \cdot \mathrm{h}^{-1}$; after the axis break, the step size is $0.01 \mathrm{~g} \cdot \mathrm{L}^{-1} \cdot \mathrm{h}^{-1}$ ). At the lowest productivity value simulated $\left(0.001 \mathrm{~g} \cdot \mathrm{L}^{-1} \cdot \mathrm{h}^{-1}\right)$, the MPSP, GWP 100 , and FEC were $\$ 93.9 \mathrm{~kg}^{-1}, 72.5 \mathrm{~kg} \mathrm{CO}_{2}-\mathrm{eq} \cdot \mathrm{kg}^{-1}$, and $894.9 \mathrm{MJ} \cdot \mathrm{kg}^{-1}$, respectively; these were the highest values obtained for those metrics across the range of productivity values simulated, and the metric values are expected to continue to increase at lower productivity values. The baseline fermentation performance is depicted by a vertical dashed line at a productivity of $0.76 \mathrm{~g} \cdot \mathrm{L}^{-1} \cdot \mathrm{h}^{-1}$ 
Neutral fermentation
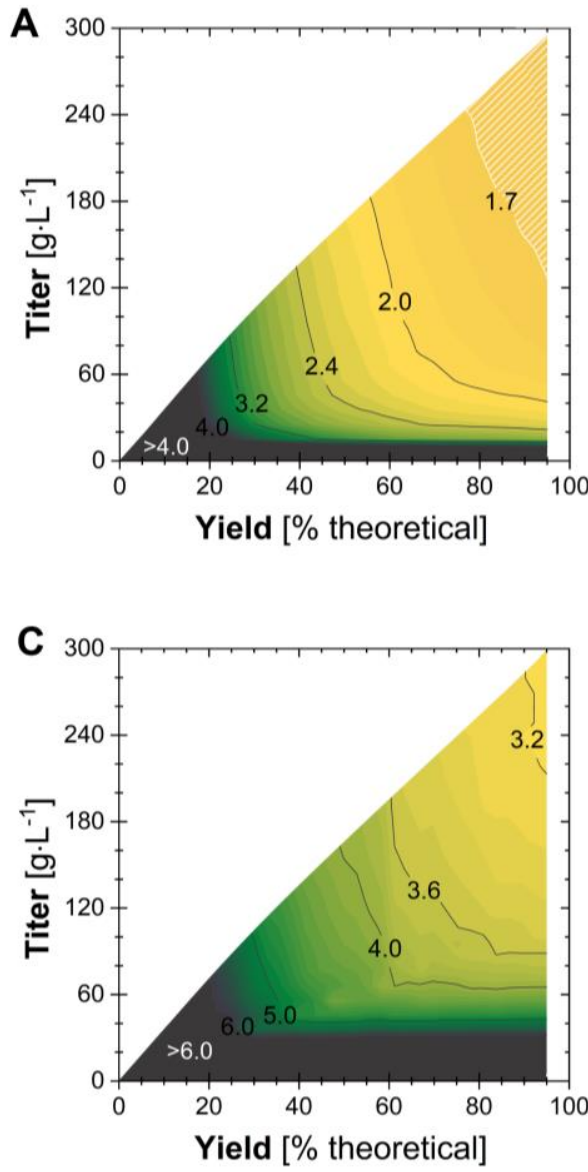

E

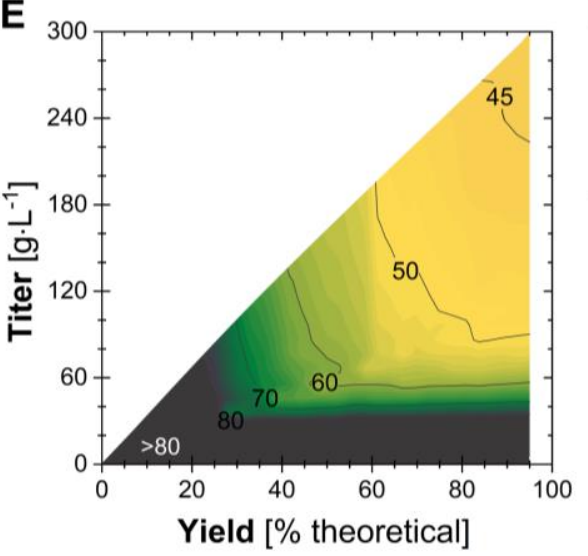

\section{Low-pH fermentation}

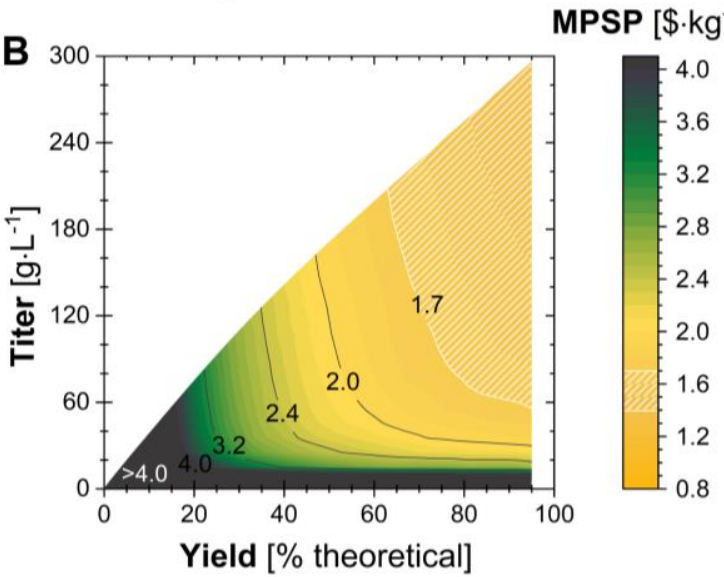

GWP

$\left[\mathrm{kg} \mathrm{CO}-\mathrm{eq} \cdot \mathrm{kg}^{-1}\right]$

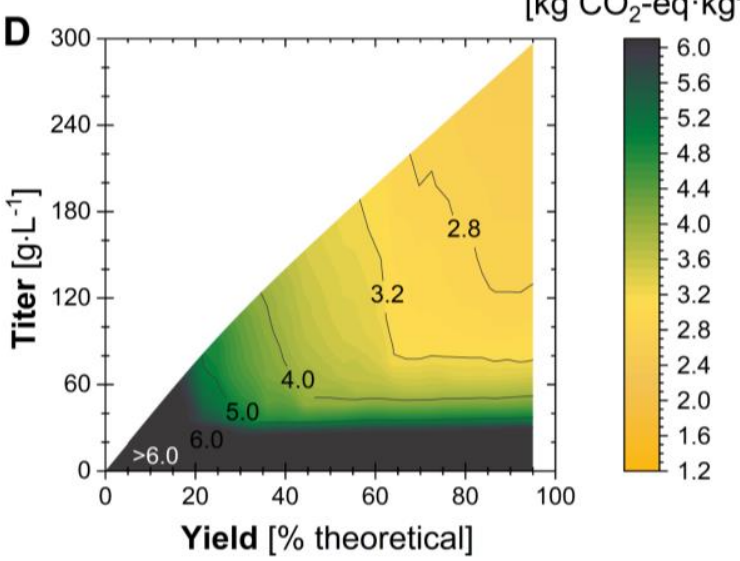

F

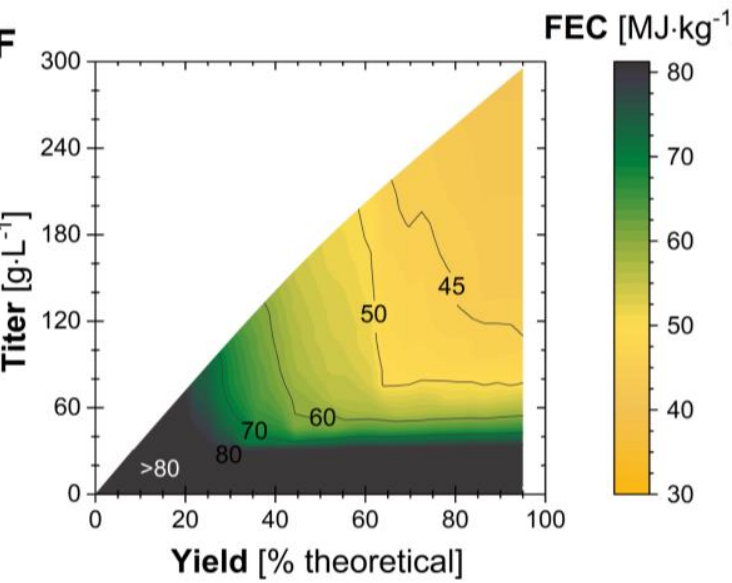

Figure S4. $(A, B)$ MPSP, $(C, D) G_{100}$, and $(E, F)$ FEC across overall yield of 3-HP on glucose and xylose (x-axis) and 3-HP titer (y-axis) for the neutral $(A, C, E)$ and low-pH $(B, D, F)$ fermentation scenarios at a productivity of $0.152 \mathrm{~g} \cdot \mathrm{L}^{-1} \cdot \mathrm{h}^{-1}$ (one-fifth of the baseline productivity). 
Neutral fermentation
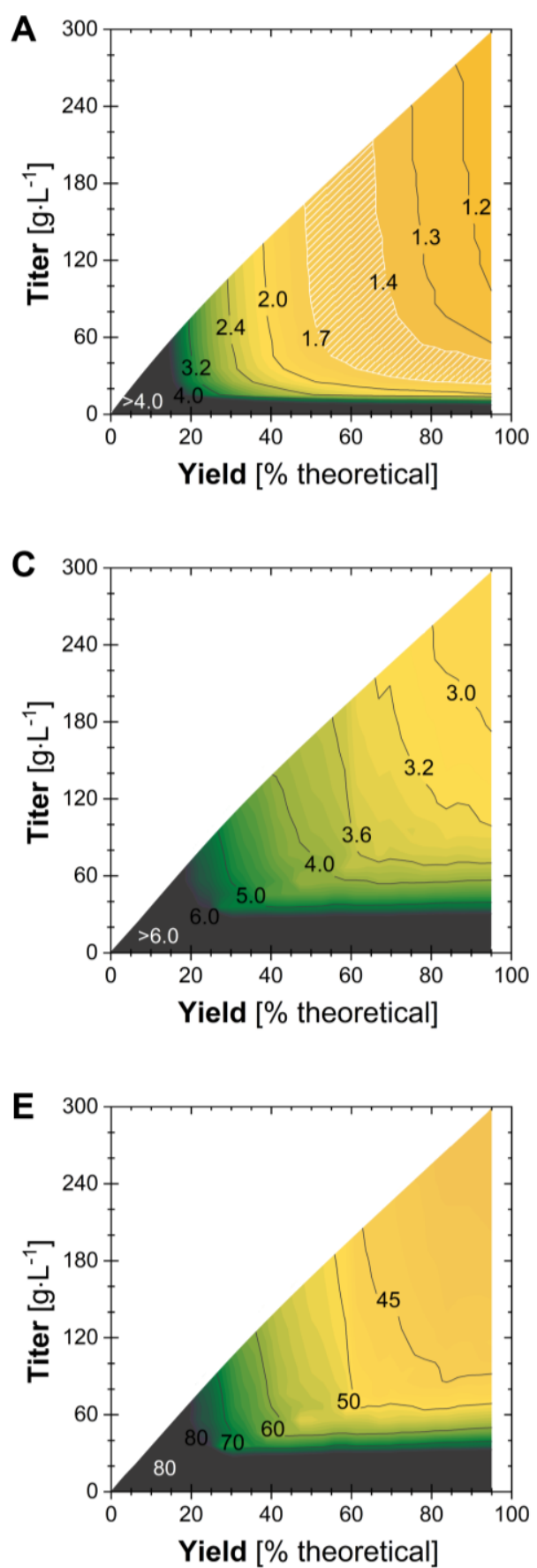

Low-pH fermentation

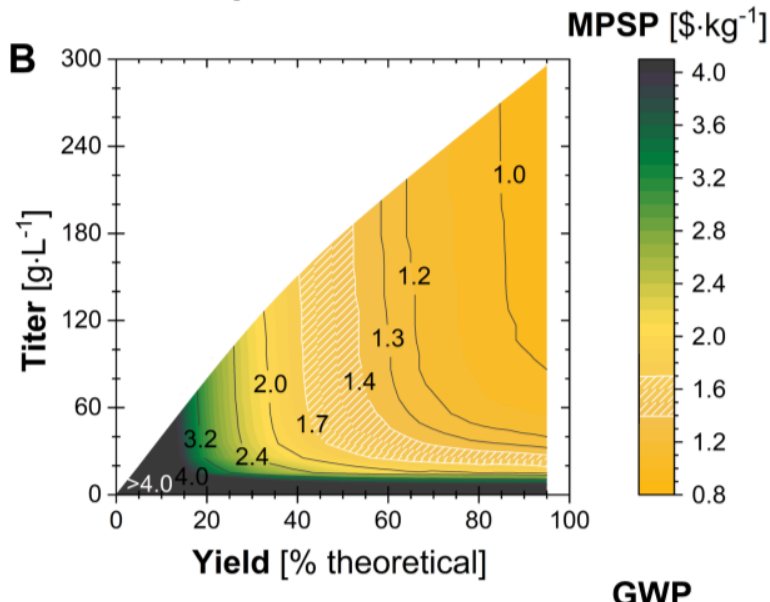

$\left[\mathrm{kg} \mathrm{CO}-\mathrm{eq} \cdot \mathrm{kg}^{-1}\right]$
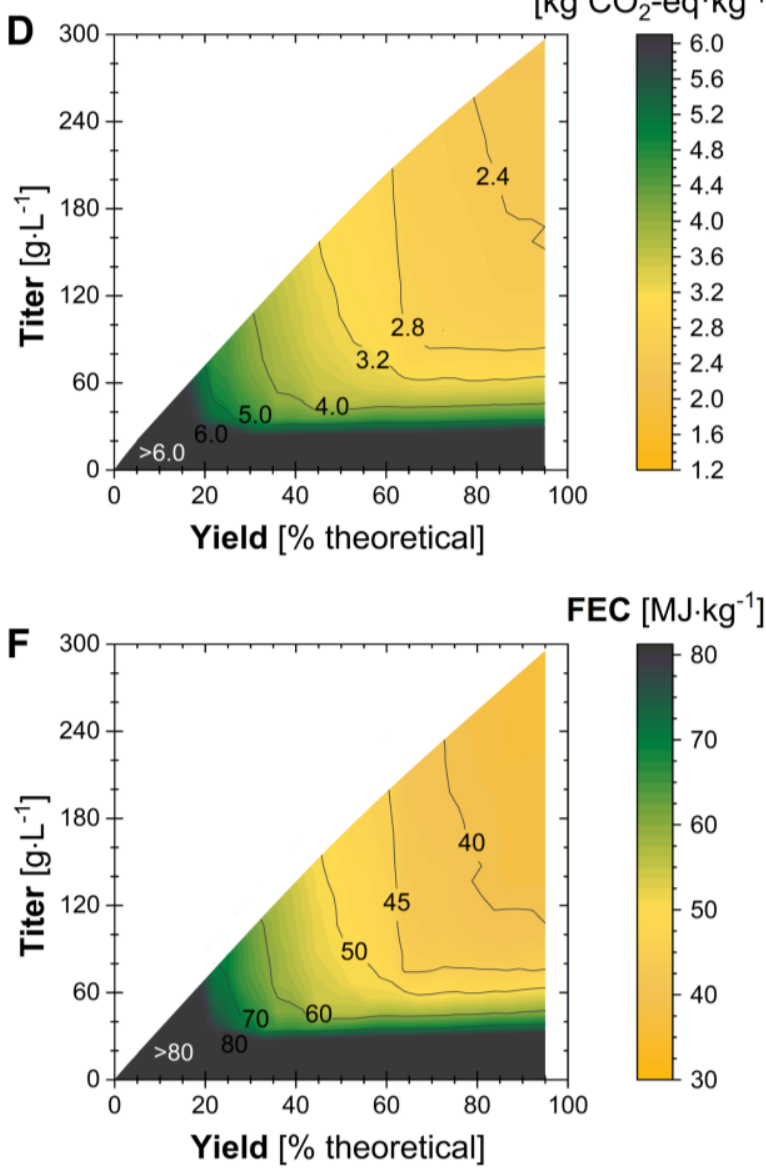

Figure S5. (A,B) MPSP, $(C, D)$ GWP $_{100}$, and $(E, F)$ FEC across overall yield of 3-HP on glucose and xylose ( $x$-axis) and 3-HP titer (y-axis) for the neutral $(A, C, E)$ and low-pH $(B, D, F)$ fermentation scenarios at a productivity of $3.80 \mathrm{~g} \cdot \mathrm{L}^{-1} \cdot \mathrm{h}^{-1}$ ( 5 times the baseline productivity). 
(i)

(ii)

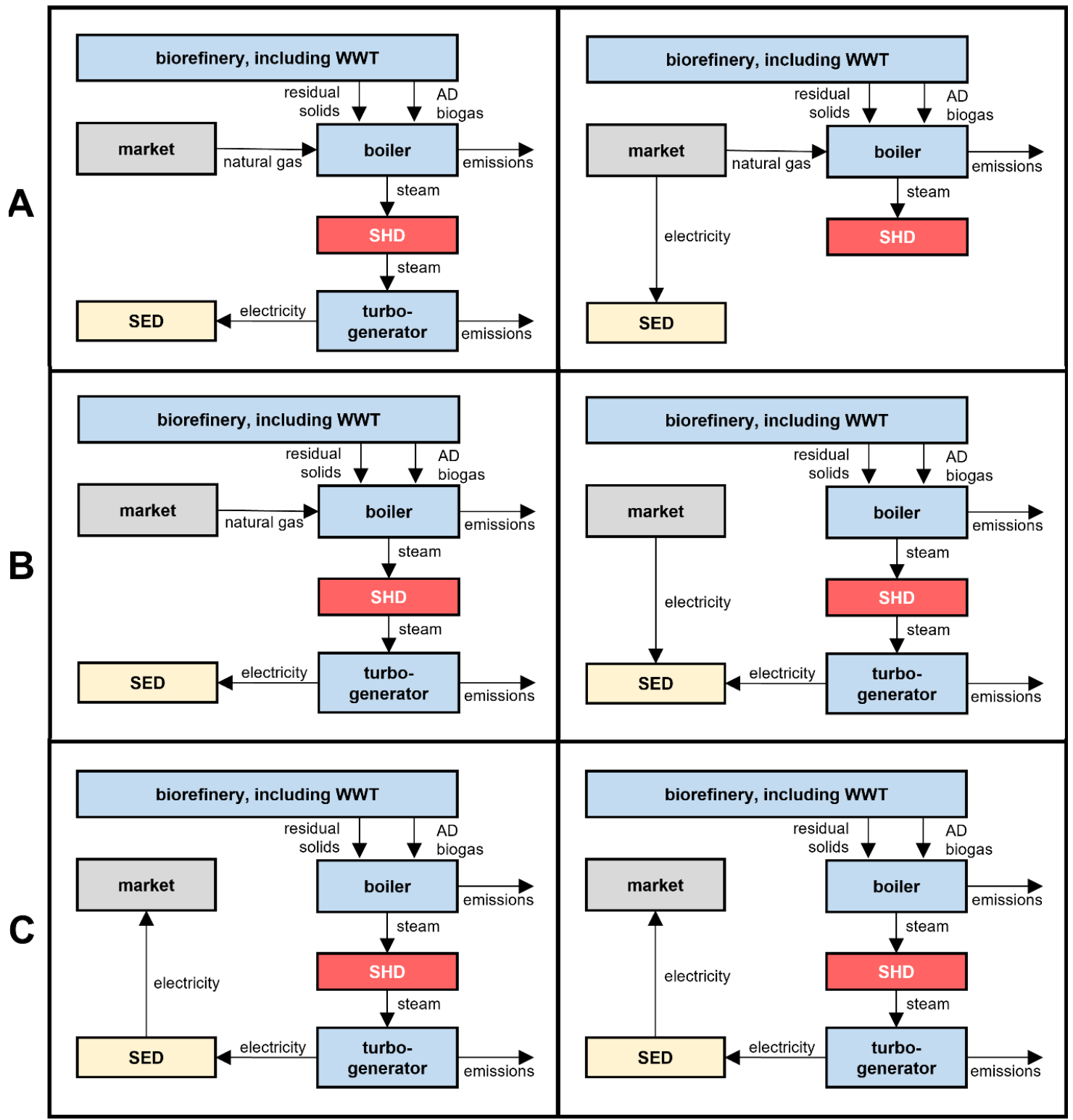

Figure S6. Case-by-case method for satisfying system heating, cooling, and non-cooling electricity demands. SHD denotes system heating demand, SED denotes system electricity demand, and AD denotes anaerobic digestion. Note that SED includes electricity used to produce cooling and chilled water as well as non-cooling electricity. The columns represent two cases that depend on the available markets for electricity and natural gas: (i) electricity is cheaper to generate from steam produced by combusting purchased natural gas than to purchase directly; or (ii) electricity is cheaper to purchase directly than to generate from steam produced by combusting purchased natural gas. The rows represent three cases that depend on biorefinery operations: the amount of steam produced in the boiler by combustion of residual solids and AD biogas is either (A) inadequate to satisfy the SHD; (B) adequate to satisfy only the SHD but not SED; or (C) adequate to satisfy both the SHD and SED. For the biorefinery presented in this study, only Column (i) is relevant, and only the cases in Rows (A) and (B) occur, but this framework may be applied to this and other biorefineries for analyses pertaining to changes in the electrical grid and biorefinery wastes with greater heats of combustion. 

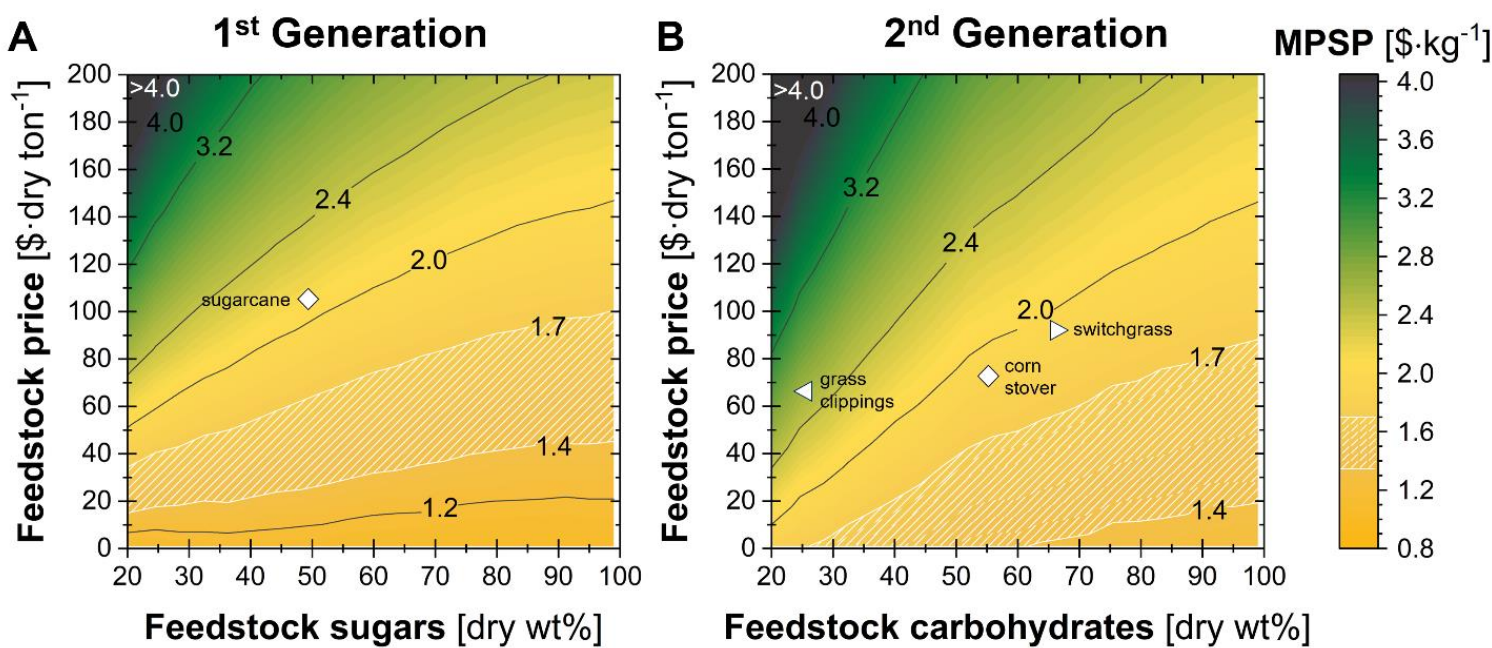

Feedstock carbohydrates [dry wt\%]

Figure S7. MPSP across (A) feedstock sugar content for $1^{\text {st }}$ generation feedstocks (x-axis), (B) feedstock carbohydrate content for $2^{\text {nd }}$ generation feedstocks ( $x$-axis), and feedstock price ( $y$-axis) for the neutral fermentation scenario. Dry weight contents of sugars (glucose, xylose, and sucrose) and carbohydrates (glucan and xylan) of representative feedstocks (sugarcane for $1^{\text {st }}$ generation; grass clippings, corn stover, and switchgrass for $2^{\text {nd }}$ generation) are also shown. Water content was fixed across all simulated sugar/carbohydrate compositions. To simulate sugar dry weight percentages greater than sugarcane (for $1^{\text {st }}$ generation) and carbohydrate dry weight percentages greater than corn stover (for $2^{\text {nd }}$ generation), other components contributing to dry weight (namely lignin, extract, ash, protein, and acetate) were decreased at fixed ratios relative to each other (i.e., the lignin:extract:ash:protein:acetate ratio was kept constant, and the dry weight percentage of all five components were reduced to accommodate increased carbohydrates). To simulate sugar/carbohydrate dry weight percentages lower than sugarcane (for $1^{\text {st }}$ generation) and corn stover (for $2^{\text {nd }}$ generation), other components contributing to dry weight (lignin, extract, ash, protein, and acetate) were increased at fixed ratios relative to each other. 


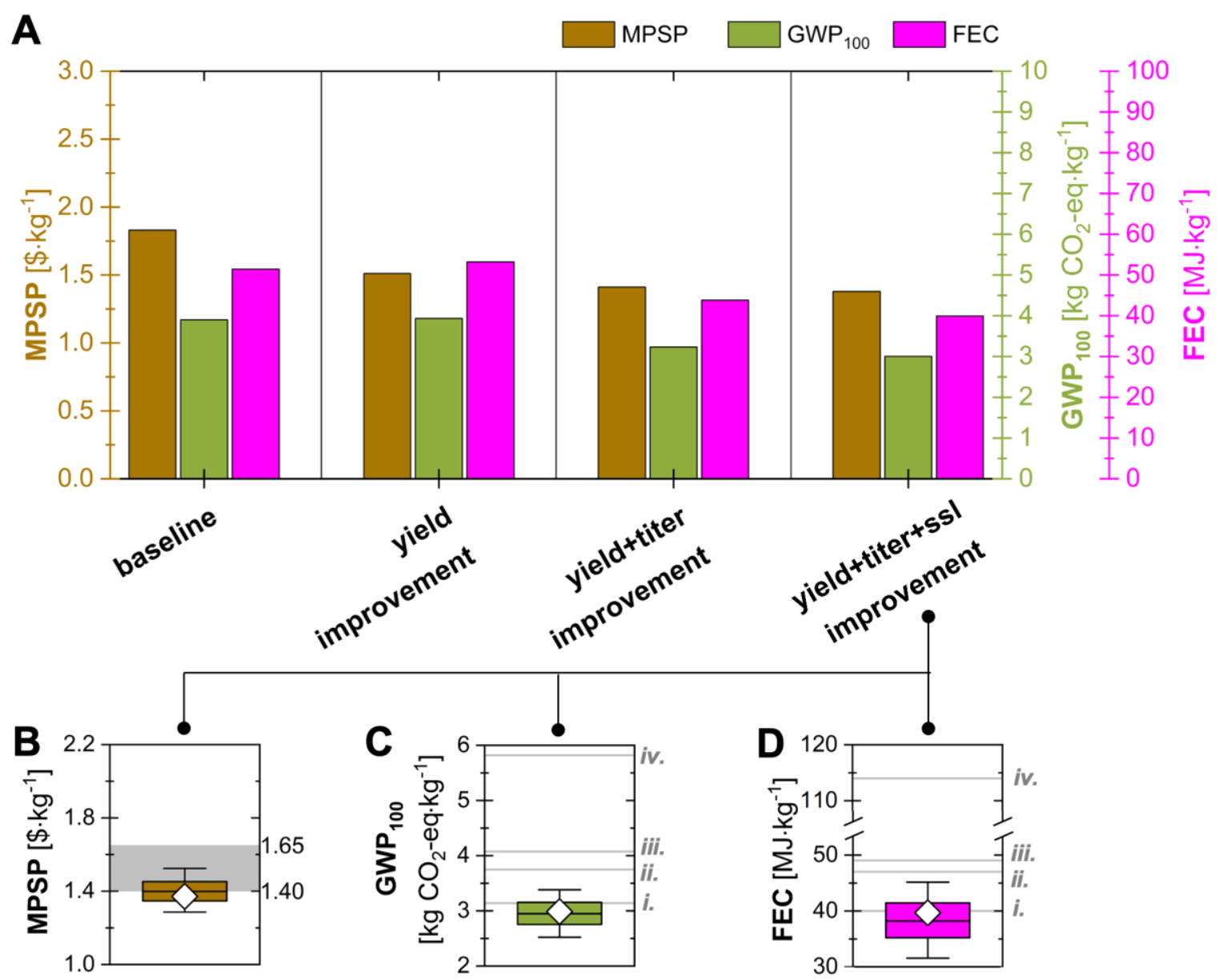

Figure S8. (A) Changes in MPSP, GWP 100 , and FEC with different technological improvements. Yield improvement ("yield"): fermentation 3-HP yield increased from $49 \%$ to $75 \%$ of theoretical yield on glucose and xylose. Titer improvement ("titer"): fermentation 3-HP titer increased from $54.8 \mathrm{~g} \cdot \mathrm{L}^{-1}$ to $109.6 \mathrm{~g} \cdot \mathrm{L}^{-1}$. Saccharification solids loading improvement ("ssl"): solids loading during saccharification increased from $20 \mathrm{wt} \%$ to $40 \mathrm{wt} \%$. (B,C,D) For the yield+titer+ssl" improvement case, an uncertainty analysis was conducted. In the uncertainty analysis, for saccharification solids loading, the upper and lower bounds as well as the most probable of the distribution listed in Table $\mathbf{S} 4$ were multiplied by a factor of 2; for yield and titer, uniform distributions of $60-90 \%$ of theoretical and $87.7-131.5 \mathrm{~g} \cdot \mathrm{L}^{-1}$ were chosen; for all other parameters, the distributions listed in Table S4 were used. Uncertainties (box-and-whisker plots) for (B) MPSP, (C) GWP ${ }_{100}$, and (D) FEC per kg of acrylic acid produced are shown. Diamonds report results for baseline values (other than for yield, titer and saccharification solids loading, for which values from the "yield+titer+ssl" improvement case were used). For MPSP, the shaded gray region shows the market price range for acrylic acid $\left(\$ 1.40-1.65 \mathrm{~kg}^{-1}\right)$. For $\mathrm{GWP}_{100}$ and FEC, gray lines marked with lowercase Roman numerals indicate (i.) bio-based acrylic acid (GREET 2020) ${ }^{41}$, (ii.) bio-based acrylic acid (Dunn et al. ${ }^{22}$ ), (iii.) fossil-based acrylic acid (ecoinvent 3.7.1), ${ }^{42,43}$ and (iv.) fossil-based acrylic acid (GREET 2020). ${ }^{41}$ Tabulated data breaking down capital and material costs, heating and cooling duties, electricity usage, $\mathrm{GWP}_{100}$, and FEC are available online. ${ }^{33}$ 


\section{Section S3. Supplementary Tables}

Table S1. List of major units and equipment included in the biorefinery.

\begin{tabular}{|c|c|c|c|c|}
\hline Process & ID & Unit & Equipment & Source \\
\hline \multirow{4}{*}{ pre-processing ${ }^{\mathrm{a}}$} & \multirow{4}{*}{ U101 } & \multirow{4}{*}{ feedstock preprocessing } & truck scale, dumper, dumper hopper & \multirow{4}{*}{ costs from ${ }^{1}$} \\
\hline & & & dust collection system & \\
\hline & & & $\begin{array}{l}\text { feedstock storage dome, reclaim } \\
\text { system }\end{array}$ & \\
\hline & & & conveyor & \\
\hline \multirow{12}{*}{ pretreatment } & T201 & sulfuric acid addition & tank, pump & 1 \\
\hline & M201 & sulfuric acid mixing & in-line mixer & 1 \\
\hline & \multirow{3}{*}{$\mathrm{R} 201$} & \multirow{3}{*}{ pretreatment } & storage bin, conveyor, feeder, preheater & 1 \\
\hline & & & $\begin{array}{c}\text { pressurized heating screw, transport, } \\
\text { discharge }\end{array}$ & \multirow[t]{2}{*}{1} \\
\hline & & & reactor & \\
\hline & T202 & blowdown & tank, agitator, pump & 1 \\
\hline & T203 & oligomer conversion & tank, agitator, pump & 1 \\
\hline & F201 & flash & tank, agitator, pump & 1 \\
\hline & $\mathrm{H} 201$ & waste vapor condensation & condenser & 1 \\
\hline & M205 & ammonia mixing & mixer & 1 \\
\hline & T204 & ammonia addition & tank, agitator & 1 \\
\hline & P201 & hydrolysate pumping & pump & 1 \\
\hline \multirow{8}{*}{ conversion } & M301 & enzyme mixing & in-line mixer & 1 \\
\hline & R301 & saccharification & enzymatic hydrolysis tank, pump & 1 \\
\hline & S301 & lignin filtration & filter, hydrolysate pump & 44 \\
\hline & F301 & $\begin{array}{l}\text { saccharified stream } \\
\text { concentration }\end{array}$ & multi-effect evaporator, pump & BioSTEAM \\
\hline & M304 & $\begin{array}{l}\text { saccharified stream } \\
\text { dilution }\end{array}$ & mixer & BioSTEAM \\
\hline & $\mathrm{R} 302$ & co-fermentation & fermenter, agitator, pump & $\begin{array}{c}\text { design based on }{ }^{1} \\
\text { and Table S2, costs } \\
\text { based on }{ }^{1}\end{array}$ \\
\hline & $\mathrm{R} 303$ & seed train & seed fermenter, agitator, pump & $\begin{array}{c}\text { design based on }{ }^{1} \\
\text { and Table S2, costs } \\
\text { based on }{ }^{1}\end{array}$ \\
\hline & T301 & seed holding & tank, agitator, pump & 1 \\
\hline \multirow{5}{*}{$\begin{array}{l}\text { waste } \\
\text { treatment }\end{array}$} & R501 & anaerobic digestion & anaerobic basin & 1 \\
\hline & $\mathrm{R} 502$ & aerobic digestion & caustic feed, aerobic basin & 1 \\
\hline & S501 & membrane bioreactor & reactor, conveyor & 1 \\
\hline & S503 & sludge centrifuge & centrifuge & 1 \\
\hline & S504 & reverse osmosis & reactor, evaporator & 1 \\
\hline
\end{tabular}

${ }^{a}$ Capital and operating costs of the pre-processing process are zero as they are included in the cost of feedstock. 
Table S1 (Continued). List of major units and equipment included in the biorefinery.

\begin{tabular}{|c|c|c|c|c|}
\hline Process & ID & Unit & Equipment & Source \\
\hline \multirow{18}{*}{ separation } & \multirow{6}{*}{ S401 } & \multirow{6}{*}{ cell mass filtration } & feed tank, pump & \multirow{6}{*}{1} \\
\hline & & & air compressor, receiver & \\
\hline & & & filter & \\
\hline & & & filtrate tank, agitator, pump & \\
\hline & & & solid screw, conveyor & \\
\hline & & & recycled water tank, wash pump & \\
\hline & $\mathrm{R} 401^{\mathrm{a}}$ & acidulation & tank, agitator, pump & BioSTEAM \\
\hline & \multirow{2}{*}{$\mathrm{S} 402^{\mathrm{a}}$} & \multirow{2}{*}{ gypsum filtration } & filter & \multirow{2}{*}{44} \\
\hline & & & hydrolysate pump & \\
\hline & $\mathrm{F} 401$ & evaporation & $\begin{array}{l}\text { multiple effect evaporator, } \\
\text { condenser }\end{array}$ & BioSTEAM \\
\hline & M401 & recycled solvent mixing & mixer & BioSTEAM \\
\hline & S404 & solvent extraction & mixers, liquid split settlers & BioSTEAM \\
\hline & D401 & distillation & rectifier, stripper, heat exchanger & BioSTEAM \\
\hline & M402 & dilution & mixer & BioSTEAM \\
\hline & $\mathrm{R} 402$ & dehydration & $\begin{array}{l}\text { tank, agitator, pump, heat } \\
\text { exchanger }\end{array}$ & $\begin{array}{c}\text { design parameters from }{ }^{22,23} \\
\text { costing from BioSTEAM }\end{array}$ \\
\hline & R402_H & $\begin{array}{l}\text { reactor effluent } \\
\text { condensation }\end{array}$ & condenser & BioSTEAM \\
\hline & D402 & distillation & rectifier, stripper, heat exchanger & BioSTEAM \\
\hline & D403 & distillation & rectifier, stripper, heat exchanger & BioSTEAM \\
\hline
\end{tabular}

a Bypassed in the acid-tolerant strain scenario (fermentation does not require lime addition, precluding the need for need for acidulation and gypsum removal). 
Table S1 (Continued). List of major units and equipment included in the biorefinery.

\begin{tabular}{|c|c|c|c|c|}
\hline Process & ID & Unit & Equipment & Source \\
\hline \multirow{24}{*}{ facilities } & T601 & acrylic acid storage & tank & BioSTEAM \\
\hline & T602 & sulfuric acid storage & tank, pump & 1 \\
\hline & T603 & ammonia storage & $\operatorname{tank}$ & 1 \\
\hline & T604 & CSL storage & tank, agitator, pump & 1 \\
\hline & $\mathrm{T}_{605}^{\mathrm{a}}$ & lime storage & storage bin, feeder, blower, baghouse & 44 \\
\hline & T606 & hexanol storage & tank & BioSTEAM \\
\hline & FWT & fire water storage & tank, pump & 1 \\
\hline & \multirow{12}{*}{ BT } & \multirow{12}{*}{ boiler and turbogenerator } & boiler & \multirow{12}{*}{ BioSTEAM } \\
\hline & & & boiler air intake fan, preheater & \\
\hline & & & boiler combustion gas baghouse & \\
\hline & & & boiler feed water preheater, pump & \\
\hline & & & boiler blowdown flash, pump & \\
\hline & & & turbogenerator, pump & \\
\hline & & & $\begin{array}{l}\text { turbogenerator condensate tank, pump, } \\
\text { surge drum }\end{array}$ & \\
\hline & & & water softener system & \\
\hline & & & deaerator, pump & \\
\hline & & & amine addition package, drum, pump & \\
\hline & & & ammonia addition package & \\
\hline & & & phosphate addition package & \\
\hline & CT & cooling tower & cooling tower system, pump & 1 \\
\hline & CWP & chilled water package & chilled water regeneration system, pump & BioSTEAM \\
\hline & PWC & process water center & tank, pump & 1 \\
\hline & ADP & air distribution package & air compressor, receiver, dryer & 1 \\
\hline & CIP & clean-in-place & CIP system & 1 \\
\hline
\end{tabular}

a Bypassed in the acid-tolerant strain scenario (fermentation does not require quicklime addition or subsequent acidulation and gypsum removal). 
Table S2. Reference literature for co-fermentation process design.

\begin{tabular}{|c|c|c|c|c|c|c|c|c|c|c|}
\hline \multicolumn{5}{|c|}{ Fermentation } & \multicolumn{5}{|c|}{$\begin{array}{r}\text { Product Analysis } \\
\end{array}$} & \multirow[t]{3}{*}{ Source } \\
\hline \multirow[b]{2}{*}{ Microbe } & \multirow[b]{2}{*}{ Substrate } & \multirow[b]{2}{*}{ Mode } & \multirow[b]{2}{*}{$\begin{array}{c}\mathbf{T} \\
{\left[{ }^{\circ} \mathrm{C}\right]}\end{array}$} & \multirow[b]{2}{*}{ pH control } & \multicolumn{3}{|c|}{ 3-Hydroxypropionic Acid } & \multirow[b]{2}{*}{$\begin{array}{c}\text { Acetic } \\
\text { Acid }^{\mathrm{a}}\end{array}$} & \multirow[b]{2}{*}{ Glycerol $^{a}$} & \\
\hline & & & & & $\begin{array}{l}\text { Titer } \\
{\left[\mathrm{g} \cdot \mathrm{L}^{-1}\right]}\end{array}$ & $\begin{array}{c}\text { Productivity } \\
{\left[\mathrm{g} \cdot \mathrm{L}^{-1} \cdot \mathrm{h}^{-1}\right]}\end{array}$ & $\begin{array}{c}\text { Yield } \\
{[\% \text { theo.] }}\end{array}$ & & & \\
\hline \multirow{2}{*}{ Saccharomyces } & Glucose & Fed-batch & 30 & 5.0 by $\mathrm{NaOH}$ & 13.7 & 0.17 & 14.0 & 0.00 & 0.00 & 45 \\
\hline & Glucose & Fed-batch & 30 & 5.0 by $\mathrm{KOH}$ & 18.1 & 0.17 & 12.5 & $-\mathrm{b}$ & $-\mathrm{b}$ & 46 \\
\hline \multirow{5}{*}{ Escherichia } & Glucose \& Xylose (2:1) & Fed-batch & \multirow{5}{*}{$\begin{array}{l}\text { Initially } 37 \\
\text { then } 25\end{array}$} & 7.0 & 29.4 & 0.54 & 36.0 & $-\mathrm{b}$ & 0.48 & 47 \\
\hline & Glucose & Fed-batch & & 7.0 by $\mathrm{NaHCO}_{3}$ & 10.1 & 0.28 & 18.0 & 0.00 & $-\mathrm{b}$ & 48 \\
\hline & Glucose & Fed-batch & & 7.0 by $\mathrm{NaHCO}_{3}$ & 31.1 & 0.63 & 42.0 & 0.05 & $-b$ & 49 \\
\hline & Glucose & Fed-batch & & 7.0 by $\mathrm{NH}_{4} \mathrm{OH}$ & 40.6 & 0.56 & 19.0 & $-\mathrm{b}$ & $-\mathrm{b}$ & 50 \\
\hline & Glucose \& Xylose (2:1) & Fed-batch & & 6.8 by $\mathrm{NH}_{4} \mathrm{OH}$ & 37.6 & 0.63 & 17.0 & 0.00 & 0.00 & 51 \\
\hline \multirow{2}{*}{ Corynebacterium } & Glucose & Fed-batch & \multirow{2}{*}{30} & 7.2 by $\mathrm{NH}_{4} \mathrm{OH}$ & 62.6 & 0.87 & 51.0 & 0.02 & 0.06 & 10 \\
\hline & Glucose \& Xylose (2:1) & Fed-batch & & 7.2 by $\mathrm{NH}_{4} \mathrm{OH}$ & 54.8 & 0.76 & 49.0 & 0.05 & 0.05 & 10 \\
\hline
\end{tabular}

a Final yield of acetic acid or glycerol (in $\mathrm{g} \cdot \mathrm{g}$-sugar ${ }^{-1}$ ); yields of other byproducts (including ethanol, malonic acid, and succinic acid) were minor in all studies that reported those data.

b Not reported. 
Table S3. Candidate solvents considered for extraction of 3-HP and associated partition data (estimated using the UNIFAC method 52 ) at $80{ }^{\circ} \mathrm{C}$. $T_{b, \text { solute }}$ and $T_{b, \text { solvent }}$ are the boiling temperatures of 3-HP and the specified solvent, respectively. In the column titled "Satisfied Constraints", constraints (i) - (iv) (discussed in Section S1.2) that are satisfied by a solvent are labeled with a $\checkmark$, and constraints that are violated by that solvent are left unlabeled. For convenience, the constraints are described again here: (i) boiling point of the solvent should be lower than 3-HP (to enable recovery of solvent as the top product of distillation, thus minimizing the risk of thermal decomposition of 3-HP); (ii) water-into-organic-phase $K<0.5$ (to limit dilution of the recovered solvent for recycle); (iii) solvent-into-aqueous-phase $K<0.05$ (to limit solvent loss); and (iv) acetic acid-into-organic-phase $K$ and glycerol-into-organic-phase $K$ should both be under 1.00 (to limit presence of impurities in the dehydration reactor). $K$ denotes partition coefficient (molar basis).

\begin{tabular}{|c|c|c|c|c|c|c|c|c|c|c|}
\hline \multirow{2}{*}{ Solvent } & \multicolumn{5}{|c|}{$\begin{array}{l}\text { Partition Coefficients } \\
\text { [molar basis] }\end{array}$} & \multirow{2}{*}{$\begin{array}{c}T_{b, \text { solute }}- \\
\boldsymbol{T}_{\boldsymbol{b}, \text { solvent }} \\
{\left[{ }^{\circ} \mathrm{C}\right]}\end{array}$} & \multicolumn{4}{|c|}{ Satisfied Constraints } \\
\hline & $\begin{array}{c}\text { Solute-into- } \\
\text { organic-phase }\end{array}$ & $\begin{array}{c}\text { Water-into- } \\
\text { organic-phase }\end{array}$ & $\begin{array}{l}\text { Solvent-into- } \\
\text { aqueous-phase }\end{array}$ & $\begin{array}{c}\text { Acetic acid- } \\
\text { into- } \\
\text { organic-phase }\end{array}$ & $\begin{array}{l}\text { Glycerol-into- } \\
\text { organic-phase }\end{array}$ & & (i) & (ii) & (iii) & (iv) \\
\hline 1,8-Octanediol & $4.65 \mathrm{E}+00$ & 4.04E-01 & 1.64E-03 & 3.71E-01 & 1.43E-01 & -87.59 & & $\checkmark$ & $\checkmark$ & $\checkmark$ \\
\hline 1-Hexanol & $3.18 \mathrm{E}+00$ & 4.63E-01 & $2.48 \mathrm{E}-02$ & 4.27E-01 & $2.75 \mathrm{E}-01$ & 22.85 & $\checkmark$ & $\checkmark$ & $\checkmark$ & $\checkmark$ \\
\hline 1-Heptanol & $1.91 \mathrm{E}+00$ & 3.62E-01 & $1.45 \mathrm{E}-02$ & 4.86E-01 & $6.81 \mathrm{E}-01$ & 1.75 & $\checkmark$ & $\checkmark$ & & $\checkmark$ \\
\hline 1-Octanol & $1.28 \mathrm{E}+00$ & 3.05E-01 & 7.87E-03 & 5.33E-01 & $1.40 \mathrm{E}+00$ & -14.95 & & $\checkmark$ & & \\
\hline 2-Ethylhexanol & $1.07 \mathrm{E}+00$ & $1.06 \mathrm{E}+00$ & $9.30 \mathrm{E}-01$ & $9.38 \mathrm{E}-01$ & $9.30 \mathrm{E}-01$ & -6.45 & & $\checkmark$ & & \\
\hline Cyclohexanol & $1.06 \mathrm{E}+00$ & 2.69E-01 & $3.49 \mathrm{E}-03$ & 5.47E-01 & $2.02 \mathrm{E}+00$ & 18.85 & $\checkmark$ & & $\checkmark$ & $\checkmark$ \\
\hline 1-Nonanol & $1.06 \mathrm{E}+00$ & 2.69E-01 & $3.50 \mathrm{E}-03$ & $5.52 \mathrm{E}-01$ & $2.02 \mathrm{E}+00$ & -33.95 & & $\checkmark$ & & \\
\hline 1-Decanol & $1.05 \mathrm{E}+00$ & $1.04 \mathrm{E}+00$ & $9.45 \mathrm{E}-01$ & $9.51 \mathrm{E}-01$ & $9.54 \mathrm{E}-01$ & -49.25 & & $\checkmark$ & & \\
\hline Cyclohexanone & 9.07E-01 & 2.45E-01 & $1.55 \mathrm{E}-03$ & $5.59 \mathrm{E}-01$ & $2.73 \mathrm{E}+00$ & 24.35 & & $\checkmark$ & & $\checkmark$ \\
\hline 1-Dodecanol & 7.97E-01 & 2.27E-01 & 7.00E-04 & $5.68 \mathrm{E}-01$ & $3.55 \mathrm{E}+00$ & -84.35 & & $\checkmark$ & & \\
\hline Propyl acetate & $6.72 \mathrm{E}-01$ & $1.51 \mathrm{E}-01$ & $1.54 \mathrm{E}-01$ & 7.06E-01 & $5.18 \mathrm{E}+00$ & 78.75 & $\checkmark$ & $\checkmark$ & & $\checkmark$ \\
\hline Butyl acetate & $6.30 \mathrm{E}-01$ & 2.06E-01 & $1.46 \mathrm{E}-04$ & 5.89E-01 & $5.51 E+00$ & 53.75 & $\checkmark$ & $\checkmark$ & & $\checkmark$ \\
\hline Diethyl sebacate & $5.03 \mathrm{E}-01$ & 2.60E-01 & $3.75 \mathrm{E}-02$ & $6.98 \mathrm{E}-01$ & $7.81 \mathrm{E}+00$ & -125.25 & & $\checkmark$ & & \\
\hline Diethyl hexyl phosphate & 4.07E-01 & 2.03E-01 & 1.41E-02 & 7.43E-01 & $1.08 \mathrm{E}+01$ & -204.25 & & $\checkmark$ & & \\
\hline Toluene & $3.14 \mathrm{E}-01$ & $1.69 \mathrm{E}-01$ & 4.63E-05 & $7.21 \mathrm{E}-01$ & $1.68 \mathrm{E}+01$ & 69.15 & $\checkmark$ & $\checkmark$ & & $\checkmark$ \\
\hline
\end{tabular}


Table S4. List of parameters included in uncertainty and sensitivity analyses.

\begin{tabular}{|c|c|c|c|c|c|c|c|}
\hline \multirow[b]{2}{*}{ Parameter } & \multirow[b]{2}{*}{ Unit } & \multirow{2}{*}{$\begin{array}{l}\text { Base- } \\
\text { line }\end{array}$} & \multirow{2}{*}{ Distributions } & \multirow{2}{*}{ References } & \multicolumn{3}{|c|}{ Spearman's rho } \\
\hline & & & & & MPSP & $\begin{array}{c}\mathrm{GWP}_{10} \\
0\end{array}$ & FEC \\
\hline \multicolumn{8}{|l|}{$L C A$} \\
\hline feedstock $^{\mathrm{a}} \mathrm{GWP}_{100}$ & $\mathrm{~kg} \mathrm{CO}_{2}$-eq.dry-kg-1 & 0.109 & $\begin{array}{c}0.096,0.129 \\
\text { uniform }\end{array}$ & $\begin{array}{l}\text { baseline from GREET } \\
(2020)^{41}, \text { range from } 53\end{array}$ & - & 0.13 & - \\
\hline feedstock ${ }^{\mathrm{a}}$ FEC & $\mathrm{MJ} \cdot \mathrm{dry}-\mathrm{kg}^{-1}$ & 1.68 & $1.33,1.76$, uniform & $\begin{array}{l}\text { baseline from GREET } \\
(2020)^{41}, \text { range from }{ }^{53}\end{array}$ & - & - & 0.11 \\
\hline \multicolumn{8}{|l|}{ TEA } \\
\hline plant uptime & $\%$ of year & $90 \%$ & $\begin{array}{c}84 \%, 90 \%, 96 \%, \\
\text { triangle }\end{array}$ & $\begin{array}{c}\text { baseline and upper bound } \\
\text { from }{ }^{3} \text {, lower bound set to } \\
\text { be consistent with upper } \\
\text { bound }\end{array}$ & -0.11 & -0.01 & -0.01 \\
\hline total capital investment & $\%$ of simulated value & $100 \%$ & $\begin{array}{c}\text { simulated value } \\
\pm 25 \% \text {, triangle }\end{array}$ & $\begin{array}{l}\text { simulated by BioSTEAM } \\
\text { (references noted in } \\
\text { scripts), range consistent } \\
\text { with }^{3}\end{array}$ & 0.03 & - & - \\
\hline feedstock price & $\$ \cdot$ dry-ton $^{-1}$ & 71.3 & $\begin{array}{c}60,71.3,83.7 \\
\text { triangle }\end{array}$ & $\begin{array}{l}\text { baseline and lower bound } \\
\text { from }{ }^{3} \text {, upper bound from }{ }^{54}\end{array}$ & 0.24 & - & - \\
\hline sulfuric acid price & $\$ \cdot \mathrm{kg}^{-1}$ & 0.0948 & $\begin{array}{l}0.0910,0.0948, \\
0.1046, \text { triangle }\end{array}$ & $\begin{array}{c}\text { baseline from }{ }^{3} \text {, range } \\
\text { calculated using price index } \\
\text { of sulfuric acid during } 2015- \\
2019 \text { from U.S. Bureau of } \\
\text { Labor Statistics }\end{array}$ & 0.02 & - & - \\
\hline quicklime price & $\$ \cdot \mathrm{kg}^{-1}$ & 0.262 & $\begin{array}{l}0.160,0.262, \\
0.288, \text { triangle }\end{array}$ & $\begin{array}{l}\text { baseline from }{ }^{3} \text {, lower } \\
\text { bound from } 56 \text {, upper bound } \\
\text { is baseline }+10 \%\end{array}$ & 0.15 & - & - \\
\hline natural gas price & $\$ \cdot \mathrm{kg}^{-1}$ & 0.253 & $\begin{array}{c}0.198,0.253, \\
0.304, \text { triangle }\end{array}$ & $\begin{array}{l}\text { range is the minimum, } \\
\text { average, and maximum } \\
\text { price during 2010-2019 }\end{array}$ & 0.04 & - & - \\
\hline $\mathrm{TiO}_{2}$ catalyst price & $\$ \cdot$ metric tonne $^{-1}$ & 2130 & $\begin{array}{c}\text { baseline } \pm 10 \%, \\
\text { triangle }\end{array}$ & $\begin{array}{c}\text { baseline is average price } \\
\text { from } 58\end{array}$ & 0.02 & - & - \\
\hline ash disposal $^{\mathrm{b}}$ & $\$ \cdot \mathrm{kg}^{-1}$ & -0.041 & $\begin{array}{l}\text { baseline } \pm 10 \%, \\
\text { triangle }\end{array}$ & baseline from ${ }^{3}$ & -0.03 & - & - \\
\hline enzyme price & $\$ \cdot \mathrm{kg}^{-1}$ & 6.16 & $\begin{array}{l}\text { baseline } \pm 10 \%, \\
\text { triangle }\end{array}$ & baseline from ${ }^{34}$ & 0.05 & - & - \\
\hline gypsum disposal ${ }^{b}$ & $\$ \cdot \mathrm{kg}^{-1}$ & 0 & $\begin{array}{c}-0.0288,0.00776 \\
\text { uniform }\end{array}$ & $\begin{array}{c}\text { lower bound from }{ }^{56}, \text { upper } \\
\text { bound from }{ }^{34}\end{array}$ & -0.15 & - & - \\
\hline $\begin{array}{c}\text { caustic materials for } \\
\text { WWT price }\end{array}$ & $\$ \cdot \mathrm{kg}^{-1}$ & 0.263 & $\begin{array}{l}\text { baseline } \pm 10 \% \\
\text { triangle }\end{array}$ & $\begin{array}{c}\text { baseline from }{ }^{34} \text { is used for } \\
\text { a } 50 \text { wt } \% \text { mixture }\end{array}$ & 0.02 & - & - \\
\hline make-up water price & $10^{-2} \$ \cdot \mathrm{kg}^{-1}$ & 0.044 & $\begin{array}{l}\text { baseline } \pm 10 \% \text {, } \\
\text { triangle }\end{array}$ & baseline from ${ }^{34}$ & -0.02 & - & - \\
\hline ammonia price & $\$ \cdot \mathrm{kg}^{-1}$ & 0.419 & $\begin{array}{c}\text { baseline } \pm 10 \% \\
\text { triangle }\end{array}$ & baseline from ${ }^{34}$ & -0.01 & - & - \\
\hline electricity price & $\$ \cdot k W h^{-1}$ & 0.070 & $\begin{array}{l}0.067,0.070, \\
0.074 \text {, triangle }\end{array}$ & $\begin{array}{l}\text { range is the minimum, } \\
\text { average, and maximum } \\
\text { price during } 2010-2019^{57}\end{array}$ & 0.01 & - & - \\
\hline \multicolumn{8}{|l|}{ Pretreatment } \\
\hline solids loading & mass $\%$ & $30 \%$ & $\begin{array}{c}25,30 \%, 40 \%, \\
\text { triangle }\end{array}$ & baseline and range from ${ }^{1}$ & -0.05 & -0.09 & -0.10 \\
\hline sulfuric acid loading & $\begin{array}{l}\mathrm{mg} \cdot \mathrm{g} \text {-dry } \\
\text { feedstock }\end{array}$ & 22.1 & $\begin{array}{c}10,22.1,35 \\
\text { triangle }\end{array}$ & baseline and range from ${ }^{1}$ & 0.00 & 0.02 & 0.03 \\
\hline $\begin{array}{c}\text { glucan-to-glucose } \\
\text { conversion }\end{array}$ & $\%$ of glucan & $9.9 \%$ & $\begin{array}{c}6 \%, 9.9 \%, 12 \% \\
\text { triangle }\end{array}$ & baseline and range from ${ }^{1}$ & -0.04 & 0.03 & 0.03 \\
\hline $\begin{array}{l}\text { xylan-to-xylose } \\
\text { conversion }\end{array}$ & $\%$ of xylan & $90 \%$ & $\begin{array}{c}80 \%, 90 \%, 92 \%, \\
\text { triangle }\end{array}$ & baseline and range from ${ }^{1}$ & -0.08 & 0.03 & 0.04 \\
\hline
\end{tabular}

a Farming (excluding credit for fixed carbon), harvest \& collection, transportation, storage, handling, and pre-processing. GREET considered only farming impacts; impacts for other processes from ${ }^{53}$ were added to the GREET value.

${ }^{\mathrm{b}} \mathrm{A}$ negative ash/gypsum disposal price indicates it is sold as a co-product. 
Table S4 (Continued). List of parameters included in uncertainty and sensitivity analyses.

\begin{tabular}{|c|c|c|c|c|c|c|c|}
\hline \multirow[b]{2}{*}{ Parameter } & \multirow[b]{2}{*}{ Unit } & \multirow[b]{2}{*}{ Baseline } & \multirow[b]{2}{*}{ Distributions } & \multirow[b]{2}{*}{ References } & \multicolumn{3}{|c|}{ Spearman's rho } \\
\hline & & & & & MPSP & GWP $_{100}$ & FEC \\
\hline \multicolumn{8}{|l|}{ Conversion } \\
\hline $\begin{array}{c}\text { saccharification solids } \\
\text { loading }\end{array}$ & mass $\%$ & $20 \%$ & $\begin{array}{l}17.5 \%, 20 \%, 25 \%, \\
\text { triangle }\end{array}$ & $\begin{array}{l}\text { baseline and range } \\
\text { from }{ }^{1}\end{array}$ & -0.05 & -0.11 & -0.13 \\
\hline $\begin{array}{l}\text { saccharification enzyme } \\
\text { loading }\end{array}$ & $\mathrm{mg} \cdot \mathrm{g}-$ glucan $^{-1}$ & 20 & $10,20,30$, triangle & $\begin{array}{l}\text { baseline and range } \\
\text { from }{ }^{1}\end{array}$ & 0.36 & 0.07 & 0.04 \\
\hline saccharification time & $\mathrm{h}$ & 24 & $0,24,56$, triangle & $\begin{array}{l}\text { baseline based on }{ }^{1}, \\
\text { range from }\end{array}$ & 0.06 & 0.01 & 0.00 \\
\hline $\begin{array}{l}\text { saccharification glucan- } \\
\text { to-glucose conversion }\end{array}$ & $\%$ of glucan & $90 \%$ & $75 \%, 90 \%, 95 \%$, triangle & $\begin{array}{l}\text { baseline and range } \\
\text { from }{ }^{1}\end{array}$ & -0.22 & 0.09 & 0.10 \\
\hline CSL loading & $g \cdot L^{-1}$ & 10 & $5,10,15$, triangle & $\begin{array}{l}\text { baseline and range } \\
\text { based on } 34\end{array}$ & 0.03 & 0.14 & 0.04 \\
\hline 3-HP yield & $\%$ theoretical & $49 \%$ & $\begin{array}{l}\text { simulated value } \pm 20 \%, \\
\text { triangle }\end{array}$ & $\begin{array}{l}\text { baseline from Table } \\
\text { S3 }\end{array}$ & -0.72 & -0.14 & -0.09 \\
\hline 3-HP titer & $g \cdot L^{-1}$ & 54.8 & $\begin{array}{l}\text { simulated value } \pm 20 \%, \\
\text { triangle }\end{array}$ & $\begin{array}{l}\text { baseline from Table } \\
\text { S3 }\end{array}$ & -0.10 & -0.16 & -0.12 \\
\hline 3-HP productivity & $g \cdot L^{-1} \cdot h^{-1}$ & 0.76 & $\begin{array}{l}\text { simulated value } \pm 20 \%, \\
\text { triangle }\end{array}$ & $\begin{array}{l}\text { baseline from Table } \\
\text { S3 }\end{array}$ & -0.04 & 0.01 & 0.00 \\
\hline $\begin{array}{c}\text { acetic acid and glycerol } \\
\text { yield }\end{array}$ & $\begin{array}{l}\% \text { theoretical; } \\
\text { each }\end{array}$ & 4.0 & $\begin{array}{l}\text { simulated value } \pm 20 \%, \\
\text { triangle }\end{array}$ & $\begin{array}{l}\text { baseline from Table } \\
\text { S3 }\end{array}$ & 0.01 & 0.00 & -0.01 \\
\hline inoculum ratio & $\%$ & $7 \%$ & $5 \%, 7 \%, 10 \%$, triangle & $\begin{array}{l}\text { baseline and range } \\
\text { based on that of } \\
\text { lactic acid }{ }^{34}\end{array}$ & 0.06 & -0.01 & -0.02 \\
\hline \multicolumn{8}{|l|}{ Separation } \\
\hline acidulation time & $\mathrm{h}$ & 1 & baseline $\pm 10 \%$, triangle & $\begin{array}{c}\text { baseline from } \\
\text { BioSTEAM mix tank }\end{array}$ & 0.02 & 0.01 & 0.01 \\
\hline gypsum separation & $\%$ & $99.5 \%$ & $\begin{array}{l}95 \%, \\
\text { triangle }\end{array}$ & baseline based on 44 & 0.01 & 0.02 & 0.03 \\
\hline dehydration conversion & $\begin{array}{l}\% \text { of calculated } \\
\text { value }\end{array}$ & $80 \%$ & $72 \%, 80 \%, 99 \%$, triangle & $\begin{array}{c}\text { baseline from }{ }^{22} \text {, } \\
\text { upper bound based } \\
\text { on }{ }^{23} \text {, } \\
\text { lower bound is } \\
\text { baseline }-10 \%\end{array}$ & -0.03 & 0.01 & 0.01 \\
\hline $\begin{array}{l}\text { dehydration feed 3-HP } \\
\text { concentration }\end{array}$ & wt\% & $30 \%$ & $\begin{array}{c}27 \%, 30 \%, 35 \% \\
\text { triangle }\end{array}$ & $\begin{array}{l}\text { baseline from }{ }^{22} \text {, } \\
\text { upper bound from } 59 \text {, } \\
\text { lower bound is } \\
\text { baseline }-10 \%\end{array}$ & -0.19 & -0.24 & -0.25 \\
\hline dehydration time & $\mathrm{h}$ & 38.2 & baseline $\pm 10 \%$, triangle & baseline based on ${ }^{23}$ & 0.02 & 0.03 & 0.03 \\
\hline \multicolumn{8}{|l|}{ Facilities } \\
\hline boiler efficiency & $\%$ & $80 \%$ & baseline $\pm 10 \%$, uniform & baseline from ${ }^{1,3}$ & -0.18 & -0.84 & -0.86 \\
\hline
\end{tabular}




\section{References}

(1) Humbird, D.; Davis, R.; Tao, L.; Kinchin, C.; Hsu, D.; Aden, A.; Schoen, P.; Lukas, J.; Olthof, B.; Worley, M.; Sexton, D.; Dudgeon, D. Process Design and Economics for Biochemical Conversion of Lignocellulosic Biomass to Ethanol: Dilute-Acid Pretreatment and Enzymatic Hydrolysis of Corn Stover; Technical Report NREL/TP-5100-47764; National Renewable Energy Lab (NREL), 2011.

(2) Jacobson, J. J.; Roni, M. S.; Lamers, P.; Cafferty, K. G. Biomass Feedstock and Conversion Supply System Design and Analysis; INL/EXT--14-32377, 1173107; 2014; p INL/EXT--14-32377, 1173107. https://doi.org/10.2172/1173107.

(3) Davis, R. E.; Grundl, N. J.; Tao, L.; Biddy, M. J.; Tan, E. C.; Beckham, G. T.; Humbird, D.; Thompson, D. N.; Roni, M. S. Process Design and Economics for the Conversion of Lignocellulosic Biomass to Hydrocarbon Fuels and Coproducts: 2018 Biochemical Design Case Update; NREL/TP-5100-71949; NREL, 2018. https://doi.org/10.2172/1483234.

(4) Yang, Y.; Sha, M. A Beginner's Guide to Bioprocess Modes-Batch, Fed-Batch, and Continuous Fermentation. 2019.

(5) Wang, X.; Khushk, I.; Xiao, Y.; Gao, Q.; Bao, J. Tolerance Improvement of Corynebacterium Glutamicum on Lignocellulose Derived Inhibitors by Adaptive Evolution. Appl Microbiol Biotechnol 2018, 102 (1), 377-388. https://doi.org/10.1007/s00253-0178627-4.

(6) Tsuge, Y.; Hori, Y.; Kudou, M.; Ishii, J.; Hasunuma, T.; Kondo, A. Detoxification of Furfural in Corynebacterium Glutamicum under Aerobic and Anaerobic Conditions. Appl Microbiol Biotechnol 2014, 98 (20), 8675-8683. https://doi.org/10.1007/s00253-014-5924-z.

(7) Sakai, S.; Tsuchida, Y.; Okino, S.; Ichihashi, O.; Kawaguchi, H.; Watanabe, T.; Inui, M.; Yukawa, $H$. Effect of Lignocellulose-Derived Inhibitors on Growth of and Ethanol Production by Growth-Arrested Corynebacterium Glutamicum R. Appl Environ Microbiol 2007, 73 (7), 2349-2353. https://doi.org/10.1128/AEM.02880-06.

(8) Cheng, Y.; Zhu, H.; Du, Z.; Guo, X.; Zhou, C.; Wang, Z.; He, X. Eukaryotic Translation Factor EIF5A Contributes to Acetic Acid Tolerance in Saccharomyces Cerevisiae via Transcriptional Factor Ume6p. Biotechnol Biofuels 2021, 14 (1), 38. https://doi.org/10.1186/s13068-021-01885-2.

(9) Klinke, H. B.; Thomsen, A. B.; Ahring, B. K. Inhibition of Ethanol-Producing Yeast and Bacteria by Degradation Products Produced during Pre-Treatment of Biomass. Appl Microbiol Biotechnol 2004, 66 (1), 10-26. https://doi.org/10.1007/s00253-004-1642-2.

(10) Chen, Z.; Huang, J.; Wu, Y.; Wu, W.; Zhang, Y.; Liu, D. Metabolic Engineering of Corynebacterium Glutamicum for the Production of 3-Hydroxypropionic Acid from Glucose and Xylose. Metabolic Engineering 2017, 39, 151-158. https://doi.org/10.1016/j.ymben.2016.11.009.

(11) Chang, Z.; Dai, W.; Mao, Y.; Cui, Z.; Wang, Z.; Chen, T. Engineering Corynebacterium Glutamicum for the Efficient Production of 3-Hydroxypropionic Acid from a Mixture of Glucose and Acetate via the Malonyl-CoA Pathway. Catalysts 2020, 10 (2), 203. https://doi.org/10.3390/catal10020203.

(12) Vidra, A.; Németh, Á. Bio-Based 3-Hydroxypropionic Acid: A Review. Period. Polytech. Chem. Eng. 2017, 62 (2), 156. https://doi.org/10.3311/PPch.10861.

(13) Abraham, T. W.; Allen, E.; Hahn, J. J.; Paraskevas, T.; Bohnert, C. E.; Frank, C. L. Recovery of 3-Hydroxypropionic Acid: Cargill, Incorporated, Wayzata, MN (USA). 10,442,748 B2.

(14) Noordam, B.; Jozef, M. P. PROCESS FOR ENZYMATIC HYDROLYSIS OF LIGNOCELLULOSIC MATERIAL AND FERMENTATION OF SUGARS. 10907183.

(15) Moussa, M.; Burgé, G.; Chemarin, F.; Bounader, R.; Saulou-Bérion, C.; Allais, F.; Spinnler, H.-E.; Athès, V. Reactive Extraction of 3-Hydroxypropionic Acid from Model Aqueous 
Solutions and Real Bioconversion Media. Comparison with Its Isomer 2-Hydroxypropionic (Lactic) Acid: Reactive Extraction of 3-HP Acid from Aqueous Solutions and Bioconversion Broths. J. Chem. Technol. Biotechnol. 2016, 91 (8), 2276-2285. https://doi.org/10.1002/jctb.4813.

(16) Burgé, G.; Moussa, M.; Saulou-Bérion, C.; Chemarin, F.; Kniest, M.; Allais, F.; Spinnler, H.-E.; Athès, V. Towards an Extractive Bioconversion of 3-Hydroxypropionic Acid: Study of Inhibition Phenomena: Evaluation of Bacterial Cell Inhibition during 3-HP Extractive Bioconversion. J. Chem. Technol. Biotechnol 2017, 92 (9), 2425-2432. https://doi.org/10.1002/jctb.5253.

(17) Bulemela, E.; Tremaine, P. R. Standard Partial Molar Volumes of Aqueous 2- and 3Hydroxypropionic Acid from 100 to $325^{\circ} \mathrm{C}$ : Functional Group Additivity in Isomers with Closely Spaced Polar Groups. J Solution Chem 2007, 36 (11-12), 1525-1546. https://doi.org/10.1007/s10953-007-9193-7.

(18) American Chemical Society. CAS Registry Number: 503-66-2, C3 H6 O3, Propanoic Acid, 3-Hydroxy-; 2020.

(19) Chemical Book. CAS No. 503-66-2, 3-Hydroxypropionic acid https://www.chemicalbook.com/ChemicalProductProperty_EN_CB6711580.htm (accessed $2021-05-02$ ).

(20) MOLBASE. 3-Hydroxypropionic acid, CAS N03-66-2 http://www.molbase.com/moldata/55.html (accessed 2020 -05-02).

(21) Chemarin, F.; Moussa, M.; Allais, F.; Trelea, I. C.; Athès, V. Recovery of 3Hydroxypropionic Acid from Organic Phases after Reactive Extraction with Amines in an Alcohol-Type Solvent. Separation and Purification Technology 2019, 219, 260-267. https://doi.org/10.1016/j.seppur.2019.02.026.

(22) Dunn, J. B.; Adom, F.; Sather, N.; Han, J.; Snyder, S.; He, C.; Gong, J.; Yue, D.; You, F. Life-Cycle Analysis of Bioproducts and Their Conventional Counterparts in GREET; ANL/ESD--14/9 Rev., 1250468; 2015; p ANL/ESD--14/9 Rev., 1250468. https://doi.org/10.2172/1250468.

(23) Dishisha, T.; Pyo, S.-H.; Hatti-Kaul, R. Bio-Based 3-Hydroxypropionic- and Acrylic Acid Production from Biodiesel Glycerol via Integrated Microbial and Chemical Catalysis. Microb Cell Fact 2015, 14 (1), 200. https://doi.org/10.1186/s12934-015-0388-0.

(24) Song, D.; Yang, J.-H.; Lee, C.-J. Conceptual Design of Water Separation Process in Glycerol-Based Acrylic Acid Production. Chemical Engineering Research and Design 2020, 156, 324-332. https://doi.org/10.1016/j.cherd.2020.01.036.

(25) Suo, X.; Zhang, H.; Ye, Q.; Dai, X.; Yu, H.; Li, R. Design and Control of an Improved Acrylic Acid Process. Chemical Engineering Research and Design 2015, 104, 346-356. https://doi.org/10.1016/j.cherd.2015.08.022.

(26) Seader, J. D.; Henley, E. J.; Roper, D. K. Separation Process Principles, 3rd Edition; John Wiley \& Sons, Inc., 2011.

(27) IHS Markit. Chemical Economics Handbook - Acrylic Acid and Esters. 2020.

(28) Kister, H. Z. Distillation Design; McGraw-Hill: Boston, MA, 1992.

(29) Cortés-Peña, Y. Thermosteam: BioSTEAM's Premier Thermodynamic Engine. JOSS 2020, 5 (56), 2814. https://doi.org/10.21105/joss.02814.

(30) BioSTEAM Development Group. Thermosteam: BioSTEAM's Premier Thermodynamic Engine. https://github.com/BioSTEAMDevelopmentGroup/thermosteam/tree/HP_sys (accessed Aug 10, 2021)

(31) Cortes-Peña, Y.; Kumar, D.; Singh, V.; Guest, J. S. BioSTEAM: A Fast and Flexible Platform for the Design, Simulation, and Techno-Economic Analysis of Biorefineries under Uncertainty. ACS Sustainable Chem. Eng. 2020, 8 (8), 3302-3310. https://doi.org/10.1021/acssuschemeng.9b07040. 
(32) Baral, N. R.; Kavvada, O.; Mendez-Perez, D.; Mukhopadhyay, A.; Lee, T. S.; Simmons, B. A.; Scown, C. D. Techno-Economic Analysis and Life-Cycle Greenhouse Gas Mitigation Cost of Five Routes to Bio-Jet Fuel Blendstocks. Energy Environ. Sci. 2019, 12 (3), 807824. https://doi.org/10.1039/C8EE03266A.

(33) BioSTEAM Development Group. HP: Acrylic Acid Production via 3-Hydroxypropionic Acid from Corn Stover and Sugarcane; Bioindustrial-Park: BioSTEAM's Premier Repository for Biorefinery Models and Results. https://github.com/BioSTEAMDevelopmentGroup/Bioindustrial-

Park/tree/HP sys/BioSTEAM\%202.x.x/biorefineries/HP (accessed Aug 10, 2021)

(34) Li, Y.; Bhagwat, S. S.; Cortés-Peña, Y. R.; Ki, D.; Rao, C. V.; Jin, Y.-S.; Guest, J. S. Sustainable Lactic Acid Production from Lignocellulosic Biomass. ACS Sustainable Chem. Eng. 2021, 9 (3), 1341-1351. https://doi.org/10.1021/acssuschemeng.0c08055.

(35) Langholtz, M. H.; Stokes, B. J.; Eaton, L. M. 2016 Billion-Ton Report: Advancing Domestic Resources for a Thriving Bioeconomy; DOE/EE-1440, ORNL/TM-2016/160, 1271651; 2016; p DOE/EE-1440, ORNL/TM-2016/160, 1271651. https://doi.org/10.2172/1271651.

(36) Roni, M. S.; Hartley, D. S.; Griffel, M.; Hu, H.; Nguyen, Q. A.; Cai, H.; Thompson, D. N. Herbaceous Feedstock 2018 State of Technology Report; INL/EXT-18-51654-Rev000, 1615147; 2020; p INL/EXT-18-51654-Rev000, 1615147. https://doi.org/10.2172/1615147.

(37) Hartley, D. S.; Thompson, D. N.; Griffel, L. M.; Nguyen, Q. A.; Roni, M. S. Effect of Biomass Properties and System Configuration on the Operating Effectiveness of Biomass to Biofuel Systems. ACS Sustainable Chem. Eng. 2020, 8 (19), 7267-7277. https://doi.org/10.1021/acssuschemeng.9b06551.

(38) Sievers, D. A.; Kuhn, E. M.; Thompson, V. S.; Yancey, N. A.; Hoover, A. N.; Resch, M. G.; Wolfrum, E. J. Throughput, Reliability, and Yields of a Pilot-Scale Conversion Process for Production of Fermentable Sugars from Lignocellulosic Biomass: A Study on Feedstock Ash and Moisture. ACS Sustainable Chem. Eng. 2020, 8 (4), 2008-2015. https://doi.org/10.1021/acssuschemeng.9b06550.

(39) BioSTEAM Development Group. Sugarcane: Ethanol Production from Sugarcane, Bioindustrial-Park: BioSTEAM's Premier Repository for Biorefinery Models and Results. https://github.com/BioSTEAMDevelopmentGroup/Bioindustrial-

Park/tree/master/BioSTEAM\%202.x.x/biorefineries/sugarcane\#id3 (accessed Aug 10, 2021)

(40) Antonopoulou, I.; Spanopoulos, A.; Matsakas, L. Single Cell Oil and Ethanol Production by the Oleaginous Yeast Trichosporon Fermentans Utilizing Dried Sweet Sorghum Stalks. Renewable Energy 2020, 146, 1609-1617. https://doi.org/10.1016/j.renene.2019.07.107.

(41) Argonne National Laboratory. GREET 2020 Model. October 10, 2020.

(42) Hischier, R., Acrylic Acid Production, RoW, Allocation, Cut-off by Classification, Ecoinvent Database Version 3.7.1.

(43) Wernet, G., Bauer, C., Steubing, B., Reinhard, J., Moreno-Ruiz, E., and Weidema, B.,. The Ecoinvent Database Version 3 (Part I): Overview and Methodology. The International Journal of Life Cycle Assessment 2016, 21 (9), 1218-1230.

(44) Aden, A.; Ruth, M.; Ibsen, K.; Jechura, J.; Neeves, K.; Sheehan, J.; Wallace, B.; Montague, L.; Slayton, A.; Lukas, J. Process Design Report for Stover Feedstock: Lignocellulosic Biomass to Ethanol Process Design and Economics Utilizing Co-Current Dilute Acid Prehydrolysis and Enzymatic Hydrolysis for Corn Stover; NREL/TP-510-32438; National Renewable Energy Lab (NREL), 2002. https://doi.org/10.2172/1218326.

(45) Borodina, I.; Kildegaard, K. R.; Jensen, N. B.; Blicher, T. H.; Maury, J.; Sherstyk, S.; Schneider, K.; Lamosa, P.; Herrgård, M. J.; Rosenstand, I.; Öberg, F.; Forster, J.; Nielsen, J. Establishing a Synthetic Pathway for High-Level Production of 3-Hydroxypropionic Acid in Saccharomyces Cerevisiae via $\beta$-Alanine. Metabolic Engineering 2015, 27, 57-64. https://doi.org/10.1016/j.ymben.2014.10.003. 
(46) Tong, T.; Tao, Z.; Chen, X.; Gao, C.; Liu, H.; Wang, X.; Liu, G.-Q.; Liu, L. A Biosynthesis Pathway for 3-Hydroxypropionic Acid Production in Genetically Engineered Saccharomyces Cerevisiae. Green Chem. 2021, 23 (12), 4502-4509. https://doi.org/10.1039/D0GC04431H.

(47) Jung, I.-Y.; Lee, J.-W.; Min, W.-K.; Park, Y.-C.; Seo, J.-H. Simultaneous Conversion of Glucose and Xylose to 3-Hydroxypropionic Acid in Engineered Escherichia Coli by Modulation of Sugar Transport and Glycerol Synthesis. Bioresource Technology 2015, 198, 709-716. https://doi.org/10.1016/j.biortech.2015.09.079.

(48) Cheng, Z.; Jiang, J.; Wu, H.; Li, Z.; Ye, Q. Enhanced Production of 3-Hydroxypropionic Acid from Glucose via Malonyl-CoA Pathway by Engineered Escherichia Coli. Bioresource Technology 2016, 200, 897-904. https://doi.org/10.1016/j.biortech.2015.10.107.

(49) Song, C. W.; Kim, J. W.; Cho, I. J.; Lee, S. Y. Metabolic Engineering of Escherichia Coli for the Production of 3-Hydroxypropionic Acid and Malonic Acid through $\beta$-Alanine Route. ACS Synthetic Biology 2016, 5 (11), 1256-1263. https://doi.org/10.1021/acssynbio.6b00007.

(50) Liu, C.; Ding, Y.; Zhang, R.; Liu, H.; Xian, M.; Zhao, G. Functional Balance between Enzymes in Malonyl-CoA Pathway for 3-Hydroxypropionate Biosynthesis. Metabolic Engineering 2016, 34, 104-111. https://doi.org/10.1016/j.ymben.2016.01.001.

(51) Heo, W.; Kim, J. H.; Kim, S.; Kim, K. H.; Kim, H. J.; Seo, J.-H. Enhanced Production of 3Hydroxypropionic Acid from Glucose and Xylose by Alleviation of Metabolic Congestion Due to Glycerol Flux in Engineered Escherichia Coli. Bioresource Technology 2019, 285, 121320. https://doi.org/10.1016/j.biortech.2019.121320.

(52) Gmehling, J.; Kleiber, M.; Kolbe, B.; Rarey, J. Phase Equilibria in Fluid Systems. In Chemical Thermodynamics for Process Simulation; John Wiley \& Sons, Ltd, 2019; pp 173321. https://doi.org/10.1002/9783527809479.ch5.

(53) Kaliyan, N.; Morey, R. V.; Tiffany, D. G. Economic and Environmental Analysis for Corn Stover and Switchgrass Supply Logistics. Bioenerg. Res. 2015, 8 (3), 1433-1448. https://doi.org/10.1007/s12155-015-9609-y.

(54) Roni, M. S.; Hartley, D. S.; Griffel, M.; Hu, H.; Nguyen, Q. A.; Cai, H.; Thompson, D. N. Herbaceous Feedstock 2018 State of Technology Report; INL/EXT-18-51654-Rev000; Idaho National Lab. (INL), Idaho Falls, ID (United States), 2020. https://doi.org/10.2172/1615147.

(55) U.S. Bureau of Labor Statistics. Producer Price Index by Commodity for Chemicals and Allied Products: Sulfuric Acid https://fred.stlouisfed.org/series/WPU0613020T1 (accessed $2020-07-31)$.

(56) National Minerals Information Center. Mineral Commodity Summaries 2020; U.S. Geological Survey, 2020.

(57) U.S. Energy Information Administration. Annual Energy Outlook https://www.eia.gov/outlooks/aeo/ (accessed 2019 -05 -22).

(58) Henan Sinowin Chemical Industry Co., Ltd.; Alibaba.com. Alibaba.Com - Factory Price Chinese Producer Supply Anatase Rutile Tio2 Titanium Dioxide. https://www.alibaba.com/product-detail/Titanium-Dioxide-Chinese-Tio2-Producer-

Supply_1600082019592.html?spm=a2700.galleryofferlist.normal_offer.d_title.a3415562T $m E g S y \& s=p$.

(59) Decoster, D.; Hoyt, S.; Roach, S. Dehydration of 3-Hydroxypropionic Acid to Acrylic Acid. WO2013192451A1, December 27, 2013. 